\title{
Synthesis, stability, and (de)hydrogenation catalysis by normal and abnormal alkene- and picolyl-tethered NHC ruthenium complexes
}

\author{
Frederick P. Malan, ${ }^{\dagger}$ Eric Singleton, ${ }^{\dagger}$ Petrus H. van Rooyen,${ }^{\dagger}$ Martin Albrecht ${ }^{* *}$ and Marilé \\ Landman $^{\dagger *}$ \\ ${ }^{\dagger}$ Department of Chemistry, University of Pretoria, 02 Lynnwood Road, Hatfield, Pretoria, 0002, South \\ Africa. \\ ${ }^{\ddagger}$ Department of Chemistry and Biochemistry, Universität Bern, Freiestrasse 3, 3012 Bern, Switzerland.
}

Email: marile.landman@up.ac.za; martin.albrecht@dcb.unibe.ch

\begin{abstract}
A series of $p$-cymene and cyclopentadienyl Ru(II)-aNHC complexes have been synthesized from 2methylimidazolium salts with either an $N$-bound alkenyl $(\mathbf{1}, \mathbf{3})$ or picolyl tether $(\mathbf{6}, 7)$. The $\mathrm{C}(5)-\mathrm{Me}$ substituted alkenyl-tethered analogues (2, 4) have also been synthesized. Ag-mediated C(2)dealkylation was a prominent side reaction that led to the formation of normally bound $\mathrm{NHC} \mathrm{Ru(II)}$ complexes, which in selected cases have been isolated $(5,8)$. A C(4)- over $\mathrm{C}(2)$-selectivity for ruthenium binding has been established by protecting the $\mathrm{C}(2)$-position with an iPr group on the imidazolium precursor, for which unique p-cymene (9) and cyclopentadienyl (10) Ru(II)-aNHC derivatives have been synthesized. All complexes were applied in the transfer hydrogenation of ketones and in secondary alcohol oxidation, with higher catalytic activity for the $p$-cymene over the cyclopentadienyl systems, as well as the alkenyl- over the picolyl-containing aNHC complexes.
\end{abstract}




\section{Introduction}

$N$-heterocyclic carbenes (NHCs) have the ability to exhibit both innocent and non-innocent behavior in metal-mediated transformation reactions. ${ }^{1-3}$ Therefore it is not surprising that these stabilizing ligands have been coordinated to most of the transition metals in a range of different oxidation states. NHCs are known to form some of the strongest $\mathrm{M}-\mathrm{C}$ bonds, ${ }^{4,5}$ and hence attempts have been directed towards the synthesis of highly electron-donating NHCs in order to better stabilize sensitive transition metal species, as well as to access high oxidation state metal species. ${ }^{2,3}$ It has also been shown that $\mathrm{C}(4) / \mathrm{C}(5)$-bound imidazolylidenes (a subclass of so-called abnormal NHCs, aNHCs) are significantly stronger donors compared to their classical C(2)-bound imidazolylidene counterparts (Figure 1). ${ }^{3}$ The enhanced donor properties imparted by aNHCs has been shown to further improve the catalytic efficiency of these metal complexes in a variety of reactions. ${ }^{2,4}$ A range of different backbone- and $N$-functionalized aNHCs have been reported with tunable donor properties that are significantly influenced by both the number and positions of heteroatoms within the heterocycle (Figure 1), with subsequent catalytic implications. ${ }^{5}$ For example, the pronounced mesoionic character of the aNHC ligand allows for the usual carbene-type stabilization when coordinated to low-valent electron-rich metals, whereas a carbanionic character may be dominant with electron-poor, high-oxidation state metal centers. ${ }^{2,6}$

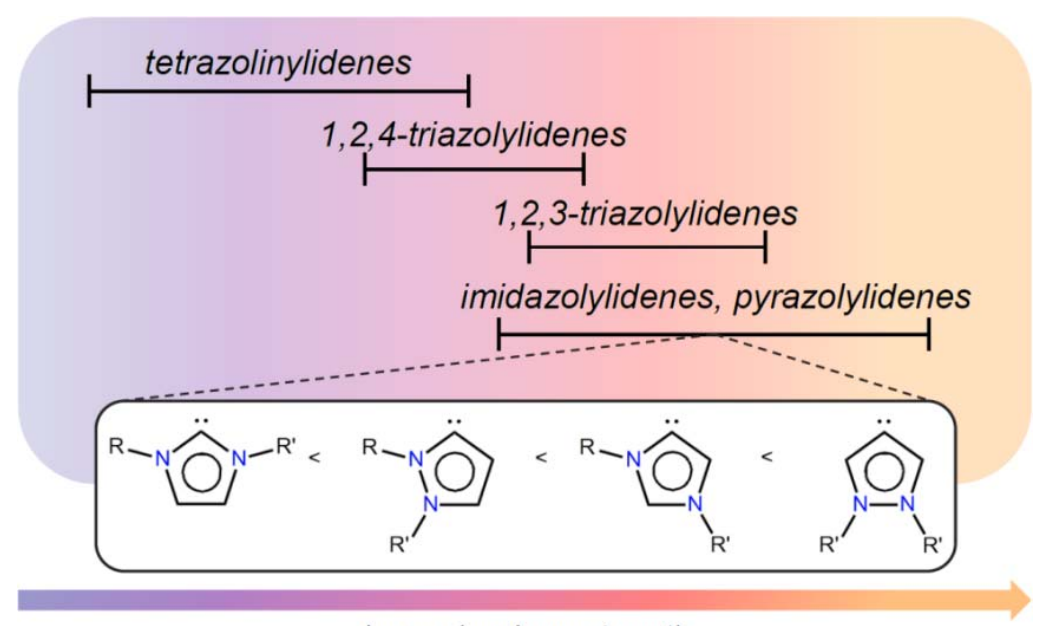

Increasing donor strength

Figure 1: Order of donor strength of imidazolylidene and pyrazolylidene-based NHCs.

Despite these attractive advantages of aNHCs, the organometallic chemistry of NHCs remains dominated by normally bound NHC complexes. ${ }^{4}$ A major limitation of aNHC complexes is the synthetic accessibility because of the low acidity of the imidazolium $C(4) / C(5)$ proton, ${ }^{7}$ which requires specific protocols to direct metalation at this position. ${ }^{7,8}$ 
Protection of the imidazolium C(2) position with alkyl or aryl substituents is probably the most rational and useful route that has been developed for selective metal coordination to the imidazolylidene $\mathrm{C}(4)$ atom. ${ }^{4,5(a)}$ However, the formation of $\mathrm{C}(4)$-bound aNHCs via transmetallation of the corresponding Ag-aNHC intermediate is generally limited because of redox reactions of the imidazolium salt with the strong oxidant $\mathrm{Ag}_{2} \mathrm{O} .{ }^{3}$ The need for more facile routes to access these desirable aNHCs remains relevant, as the rational preparation of aNHC metal complexes continues to be a synthetic challenge. ${ }^{4,9,10}$ One attractive strategy, particularly for aNHCs, is chelate-assisted C$\mathrm{H}$ bond activation. ${ }^{11}$ In this approach a variety of donor groups such as alkenyl, picolyl, pyridyl, thioether, amine, oxo, or phosphine substituents are grafted onto the $\mathrm{C}(2)$-protected NHC scaffold, usually through $\mathrm{N}$-alkylation, essentially forming a bidentate aNHC ligand precursor. Abnormal coordination selectivity has also been related to steric control imparted by the tether length and the bite angle, as well as to the nature of the anion of the aNHC precursor. ${ }^{12}$ In addition, such $N$ substituted chelators may exhibit hemilability and non-innocent behavior in solution, which enhances the set of metal-specific steps within a potential catalytic cycle. ${ }^{13}$ In light of the latter, the lack of exploitation of potentially hemilabile bidentate aNHC ligand systems prompted us to evaluate the catalytic potential of chelating aNHC ligands when bound to a ruthenium metal center. Even though only a small number of well-defined aNHC Ru complexes have been reported to date, most of these complexes exhibit superior catalytic activities compared to their normally bound analogues. ${ }^{3(a), 14}$ Here we report the synthesis of eight new abnormally bound NHC half-sandwich Ru(II) complexes and demonstrate the strong binding of these aNHC ligands through acid stability studies. In addition, the novel complexes have been evaluated for their application in transfer (de)hydrogenation catalysis. Each of these $\mathrm{Ru}$ (II) complexes is comprised of either an alkene- or picolyl-substituent as one of two possible $N$-functionalized chelating moieties. In addition, selectivity and yield issues typically encountered with $\mathrm{Ag}_{2} \mathrm{O}$-assisted carbene transfer reactions are addressed.

\section{Results and Discussion}

Synthesis of the NHC ligands. The four aNHC ligand precursors $[\mathrm{HL1}] \mathrm{Cl}-[\mathrm{HL} 4] \mathrm{Cl}$ were synthesized from the respective $C(2)$-substituted imidazoles (Scheme 1). For example, 1,2dimethylimidazole reacts with either 3-chloro-2-methyl-propene or 2-(chloromethyl)pyridine in a quaternization reaction to produce the $\mathrm{C}(2)$-protected imidazolium chloride salts in excellent yields (93\%, [HL1] Cl; 88\%, [HL2]Cl). The tetra-substituted imidazolium salt [HL3]Cl was accessed by reacting 2,4-dimethylimidazole first with acetic anhydride, followed by methyl iodide to selectively yield the 1,2,5-trimethyl imidazole. It was found previously that direct deprotonation and alkylation 
of 2,4-dimethylimidazole gave mixtures of the 1,2,4-, and 1,2,5-trisubstituted imidazoles. ${ }^{15}$ The 1,2,5trimethylimidazole precursor was further reacted with 3-chloro-2-methyl-propene to obtain [HL3]Cl in moderate yield (53\%). In an attempt to address selectivity issues in the metalation (see below), the symmetrical aNHC precursor [HL4]Cl was synthesized in high yield by sequential treatment of 2isopropylimidazole with $\mathrm{KOH}$ and 3-chloro-2-methylpropene, followed by another equivalent of 3chloro-2-methyl-propene (90\%).
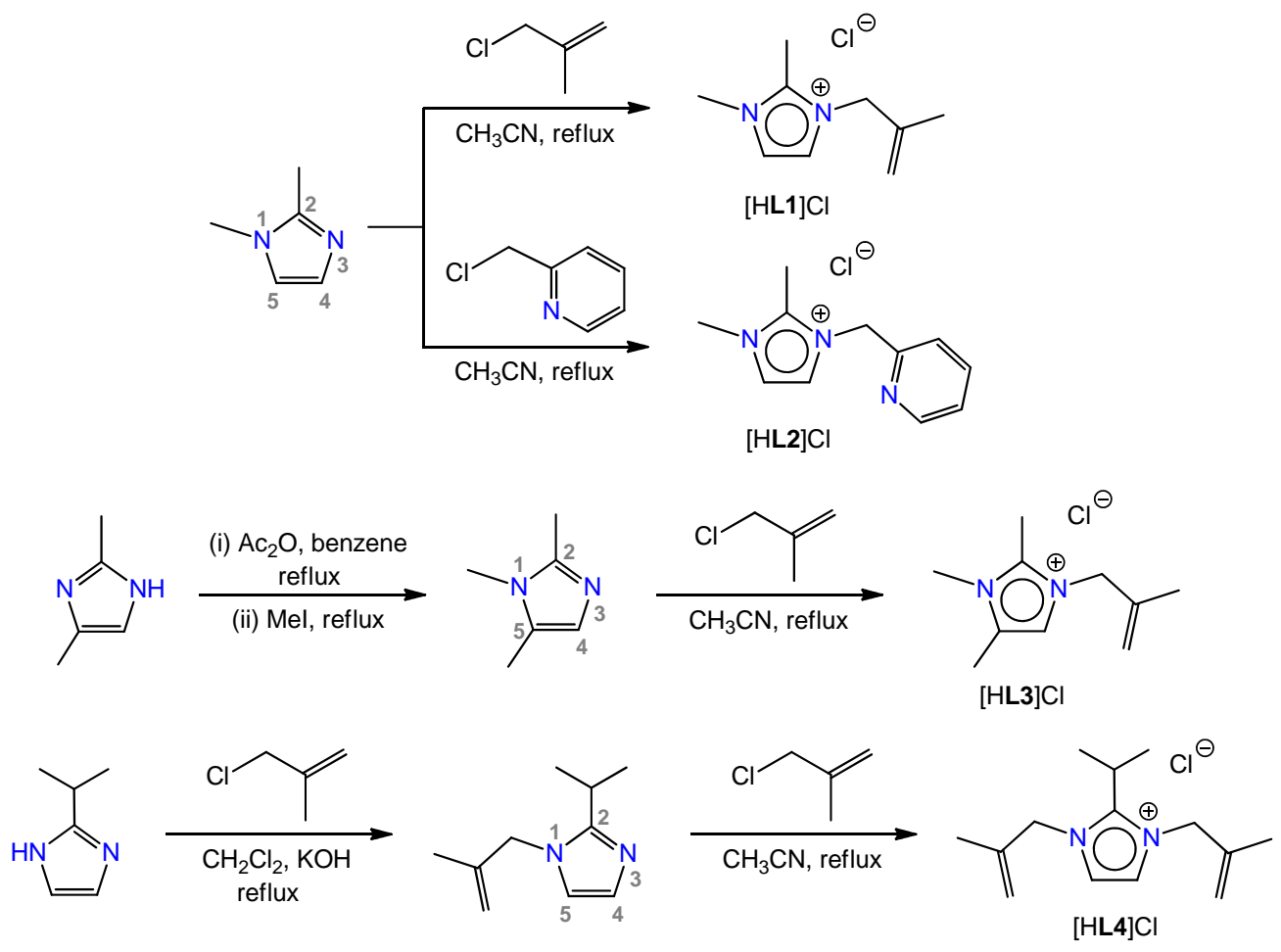

Scheme 1: Synthesis of the aNHC ligand precursors.

The ${ }^{1} \mathrm{H}$ NMR spectra of [HL1]Cl, [HL3]Cl, and [HL4]Cl all showed characteristic singlets for the 2methylpropenyl moiety at $\delta_{\mathrm{H}} 1.53-1.78\left(\mathrm{CH}_{3}\right), 4.60-4.82\left(\mathrm{NCH}_{2}\right)$, and 4.51-5.06 (two singlets, $=\mathrm{CH}_{2}$ ). Depending on the symmetrical nature of the ligand, the imidazolium backbone protons either appeared as a singlet at $\delta_{\mathrm{H}} 7.47([\mathrm{HL} 4] \mathrm{Cl})$ or $7.14([\mathrm{HL} 3] \mathrm{Cl})$, or as two singlets $\left(\delta_{\mathrm{H}} 7.51\right.$ and 7.78 for [HL1]Cl, 7.46 and 7.64 for [HL2]Cl). ${ }^{16}$ Although only ${ }^{13} \mathrm{C},{ }^{15} \mathrm{~N},{ }^{31} \mathrm{P}$, and ${ }^{77} \mathrm{Se}$ NMR techniques are classically used to compare $\sigma$-donor and $\pi$-accepting properties of various NHC ligands, ${ }^{17}$ it is interesting to compare the values of the aromatic imidazolium ${ }^{1} \mathrm{H}$ NMR signals of L1-L4 to gauge $\sigma$-donor strength: $\mathbf{L} \mathbf{1}<\mathbf{L} \mathbf{2}<\mathbf{L} \mathbf{4}<\mathbf{L 3}$. According to this series, ligand $\mathbf{L} 3$ bearing a C(5)-Me group is more donating than its $\mathrm{C}(5)-\mathrm{H}$ counterpart, $\mathbf{L} \mathbf{1}$, as might be expected from the inductive effect of a 
methyl substituent. This approximate donor strength series is supported when comparing the increasing resonance frequency of the pre-carbenic $\mathrm{C}(4)$-signal in the ${ }^{13} \mathrm{C}$ NMR spectra in the series 122.4 ppm ([HL2]Cl) 122.9 ppm ([HL1]Cl), 123.7 ppm ([HL4]Cl), 129.7 ppm ([HL3]Cl).

Synthesis of the normal and abnormal NHC Ru(II) complexes. Each of the ligands L1-L4 contains a C(2)-alkyl substituent to inhibit metal coordination at the normal position of the NHC. Metallation was carried out using standard literature procedures ${ }^{3,18}$ which involves reacting the imidazolium salt with $\mathrm{Ag}_{2} \mathrm{O}$ under exclusion of light to form the carbene silver complex in situ, and subsequently treating the reaction mixture with the appropriate ruthenium(II) precursor (Scheme 2). This procedure afforded the aNHC ruthenium(II) complexes $\mathbf{1}$ and $\mathbf{2}$ from the reaction of [HL1]Cl and $[\mathrm{HL} 3] \mathrm{Cl}$, respectively, with $\left[(p \text {-cymene }) \mathrm{RuCl}_{2}\right]_{2}$ in moderate yield $(49 \%$ and $38 \%$, respectively). ${ }^{19}$ Transmetallation with $\left[\mathrm{CpRuCl}\left(\mathrm{PPh}_{3}\right)_{2}\right]$ gave the aNHC complexes $\mathbf{3}$ and $\mathbf{4}$, respectively. While complex 3 was the only detectable product when starting from the trisubstituted imidazolium salt $[\mathrm{HL1}] \mathrm{Cl}$, the tetrasubstituted imidazolium salt [HL3] $\mathrm{Cl}$ afforded, in addition to the aNHC complex 4, also the normal NHC complex 5. Similar C(2)-Calkyl bond cleavage was observed previously, ${ }^{3(b)}$ in particular with methyl, ethyl, and benzyl substituents at $C(2) .{ }^{4(b)}$ Conversely, no dealkylation occurs when the $\mathrm{C}(2)$ substituent is a bulky, secondary alkyl or an aryl group such as iso-propyl or phenyl. ${ }^{1(\mathrm{~d}), 3(\mathrm{~b})}$ The yields of complexes 1-5 were only moderate (19-49\%), and complexes 1 and 2 formed slightly better ( $>38 \%$ yields) owing to the higher reactivity of [( $p$ cymene $\left.) \mathrm{RuCl}_{2}\right]_{2}$ vs. [CpRuCl$\left.\left(\mathrm{PPh}_{3}\right)_{2}\right]$.

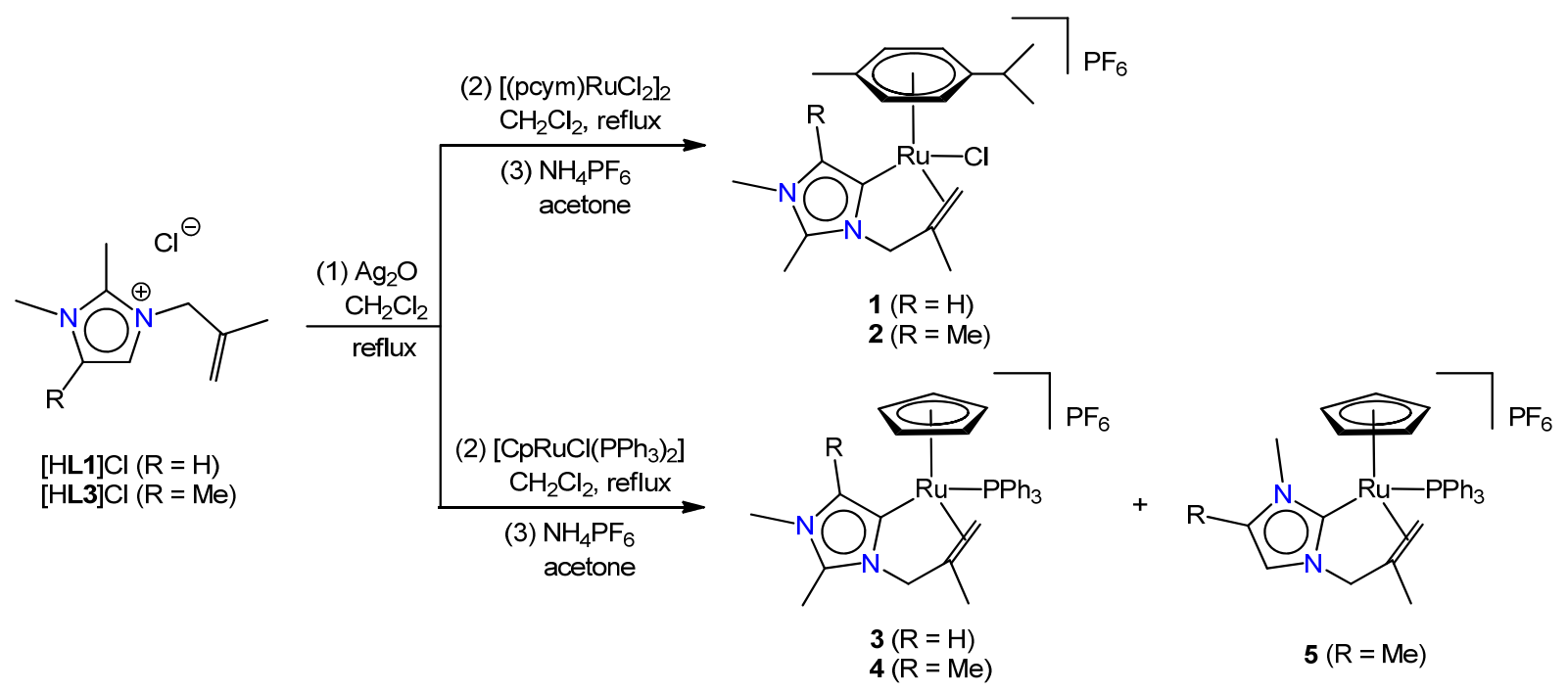

Scheme 2: Synthesis of aNHC half-sandwich Ru(II) complexes with an alkenyl chelating group. 
Spectroscopic evidence of aNHC coordination in complexes 1-4 was obtained from the disappearance of the low-field ${ }^{1} \mathrm{H}$ NMR signal due to the $\mathrm{C}(4)-\mathrm{H}$ proton and the downfield shift of the corresponding ${ }^{13} \mathrm{C}$ NMR resonance from around $125 \mathrm{ppm}$ to $147.0-171.1 \mathrm{ppm}$. Moreover, the ${ }^{1} \mathrm{H}$ NMR signals for the spectator $p$-cymene or cyclopentadienyl ligand appeared in an equimolar ratio to the carbene ligand. In addition, a slight upfield shift of the $\mathrm{C}(5)-\mathrm{H}$ proton was observed from $\delta_{\mathrm{H}}$ 7.51 in $[\mathrm{HL1}] \mathrm{Cl}$ to 7.41 (1) and 7.02 (3), respectively, indicative of higher electron density on the $\mathrm{C}(4)$ position. Alkene coordination was also confirmed by ${ }^{1} \mathrm{H}$ NMR spectroscopy, as the signals of the symmetric $\mathrm{NCH}_{2}$ methylene protons from the ligand salts (singlet around $\delta_{\mathrm{H}} 4.7$ ) split into $\mathrm{AB}$ doublets upon coordination $\left({ }^{2} J_{\mathrm{HH}}=9-15 \mathrm{~Hz}\right)$ due to their diastereotopic nature. The generally large chemical shift differences between the coupling doublets ( $\Delta \delta$ up to $1.6 \mathrm{ppm}$ ) indicates distinctly different chemical environments for the two $\mathrm{NCH}_{2}$ protons, which suggests rigid alkene coordination.

Despite successive attempts, complete separation of $\mathbf{4}$ and $\mathbf{5}$ by either column chromatography or solvent extraction has failed so far. The ${ }^{1} \mathrm{H}$ and ${ }^{31} \mathrm{P}$ NMR spectrum of the mixture of abnormal/normal NHC complexes indicates an approximate 2:1 ratio of $\mathbf{4}$ and 5. Characteristically, the aNHC complex 4 features an NMR signal at $\delta_{\mathrm{H}} 2.92$ for the $\mathrm{C}(2)-\mathrm{CH}_{3}$ protons, whereas complex 5 shows a diagnostic resonance at $\delta_{\mathrm{H}} 6.74$ for the $\mathrm{C}(4)$-bound proton. The presence of a methyl substituent on $\mathrm{C} 5$ in ligand L3 leads to a substantial preference for C(2)-dealkylation and provides the normally bound NHC as the major product. This result is attributed to a lower acidity of the $\mathrm{C}(4)-\mathrm{H}$ proton in $[\mathrm{HL} 3] \mathrm{Cl}$ (cf. NMR data), which reduces the deprotonation propensity of $\mathrm{Ag}_{2} \mathrm{O}$ in favor of $\mathrm{C}(2)-\mathrm{Me}$ oxidation.

Upon changing the type of chelate from an olefin to pyridine, i.e. employing [HL2]Cl with an $N$ picolyl substituent, provided a similar outcome and afforded complexes 6-8 in moderate yields (Scheme 3). Even though imine interactions with $\mathrm{Ag}^{+}$are more prominent, ${ }^{12}$ yields of aNHC-Ru(II) complexes did not appreciably increase compared to complexes 1-4 with an olefin wingtip functionality. Again, abnormal NHC coordination was indicated by the disappearance of the ${ }^{1} \mathrm{H}$ NMR signal of $\mathrm{C}(4)-\mathrm{H}\left(\delta_{\mathrm{H}} 7.64\right.$ in [HL2]Cl), along with a slight upfield shift of $\mathrm{C}(5)-\mathrm{H}\left(\delta_{\mathrm{H}} 6.58\right.$ and 6.64 for 6 and 7, respectively), as well as the deshielding of the corresponding C(4)-Ru carbene signal to $\delta_{\mathrm{C}} 157.8$ and 159.9 , respectively. Chelation of the picolyl moiety was supported by the characteristic downfield shift of the ortho proton of the pyridyl substituent $\left(\delta_{\mathrm{H}} 9.36\right.$ for $\mathbf{6} ; 8.25$ for 7$)$ and by the splitting of the methylene linker into an $\mathrm{AB}$ signal $\left({ }^{2} J_{\mathrm{HH}}=15-18 \mathrm{~Hz}\right)$. Separation attempts of complexes $\mathbf{7}$ and $\mathbf{8}$ failed, even after numerous attempts at recrystallization and column chromatography. Distinct NMR signals of the $\mathrm{C}(4 / 5)-\mathrm{H}$ at $\delta_{\mathrm{H}} 6.34$ and 6.44 as well as a low-field resonance at $\delta_{\mathrm{C}} 184.4$ for the $\mathrm{C}(2)-\mathrm{Ru}$ nucleus indicate the presence of the normally bound NHC 
ruthenium complex 8 in about equal quantities (ratio 7/8 is $0.46: 0.54$ according to ${ }^{1} \mathrm{H}$ and ${ }^{31} \mathrm{P}$ NMR integration).

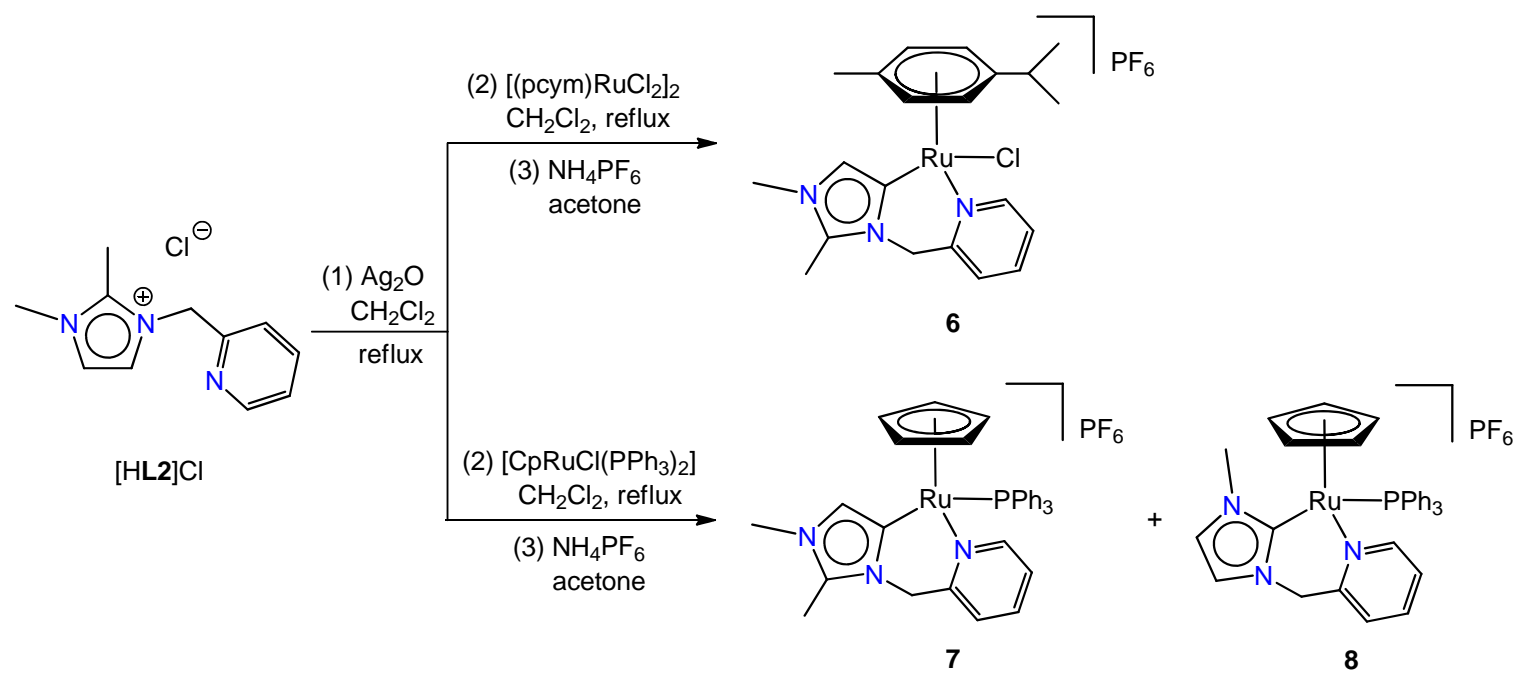

Scheme 3: Synthesis of picolyl-functionalized aNHC half-sandwich Ru(II) complexes.

Crystallographic characterization of the complexes. The molecular structures and carbene bonding modes deduced from NMR studies were unequivocally supported by X-ray diffraction studies for complexes 1, 3, and 5-8 (Figure 2, Figure 3). ${ }^{20,21,22}$ All of the half-sandwich Ru(II) complexes assumed the typical three-legged piano stool structures. ${ }^{18}$ Selected bond lengths and angles are summarized in Table 1 and Table S4 (SI). If chelation of the alkene-tether in complexes $\mathbf{1}-\mathbf{4}$ is considered to form pseudo-five membered ruthenacyles, the resulting bite angles vary between $89.49(1)$ and $90.45(2)^{\circ}$, marginally wider than with the normally bound NHC in 5 at $89.10(1)^{\circ}$. The picolyl-containing complexes 6-8 feature a six-membered metallacycle and exhibit slightly more acute chelate bite angles of $85.7(3)-86.6(2)^{\circ}$. They exhibit synclinal torsion angles between the pyridyl and imidazolylidene mean planes between $-48.60(3)$ and $-55.08(6)^{\circ}$, while the alkenecontaining complexes $(\mathbf{1}, \mathbf{3}, \mathbf{5})$ exhibit anticlinal torsion angles in the $-108.369(4)^{\circ}$ to $-122.675(2)^{\circ}$ range. This inclination renders the NHC and the alkene units closer to a co-planar arrangement. Interestingly, the $\mathrm{Ru}-\mathrm{C}(4)$ bond distance of the aNHC complexes (average $\mathrm{Ru}-\mathrm{C} 2.05(1) \AA$ for complexes $1,3,6,7)$ is shorter than the $\mathrm{Ru}-\mathrm{C}(2)$ bond distance in the normal NHC complex $8(\mathrm{Ru}-$ C 2.099(4) $\AA$ ). This might either point to a stronger $\mathrm{Ru}-\mathrm{C}(4)$ bond (abnormal vs. normal NHC), or may be due to the presence of a potentially shielding pseudo-ortho methyl group in $\mathbf{8}$. All $\mathrm{Ru}-\mathrm{C}_{\text {carbene }}$ bond distances are in good correlation with the bond distances of other related normal ${ }^{18}$ and abnormal $^{21,23} \mathrm{NHC} \mathrm{Ru(II)} \mathrm{complexes.}$ 

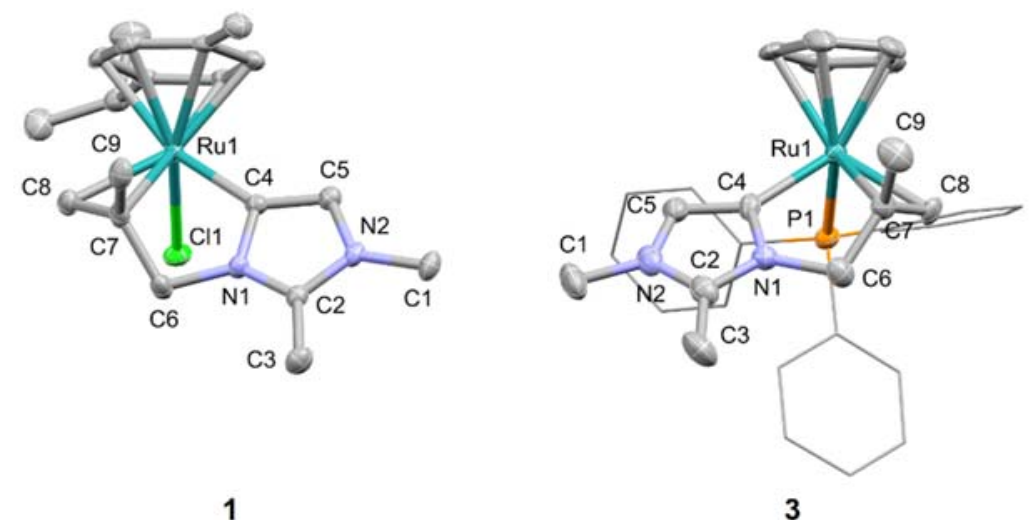

1

Figure 2: ORTEP plots of compounds 1 and 3. Thermal ellipsoids are drawn at 50\% level. For clarity, the phenyl moieties of $\mathrm{PPh}_{3}$ are shown as wireframe presentations, and non-coordinating anions and hydrogens are omitted.

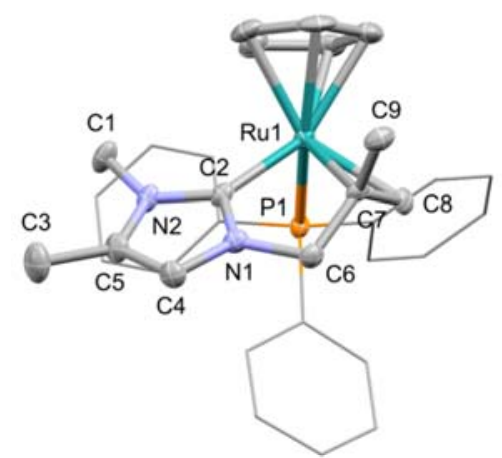

5

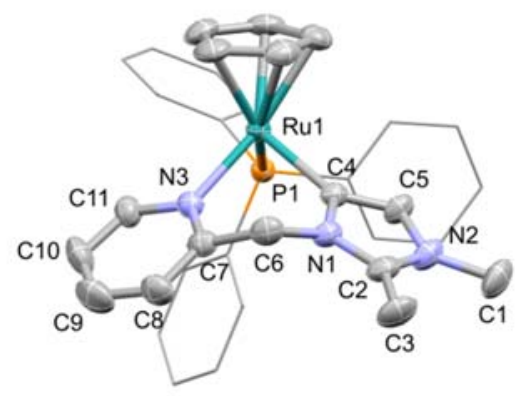

7

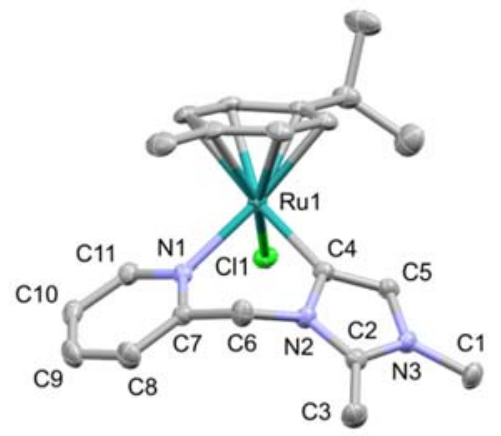

6

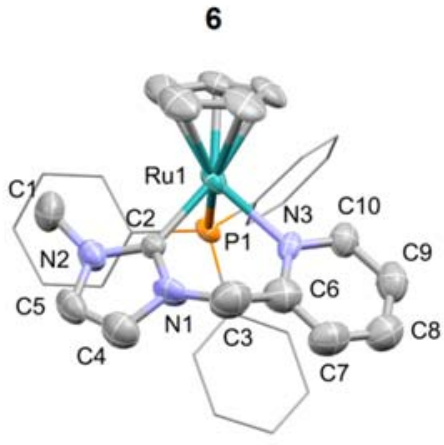

8

Figure 3: ORTEP plots of complexes 5-8. Thermal ellipsoids are drawn at 50\% level. For clarity, the phenyl moieties of $\mathrm{PPh}_{3}$ are shown as wireframe presentations, and non-coordinating anions and hydrogens are omitted (structures of $\mathbf{7}$ and $\mathbf{8}$ have been obtained from a co-crystal). 
Table 1: Selected bond lengths $(\AA)$ and angles $\left({ }^{\circ}\right)$ of complexes 1, 3, 5-8, and 10

\begin{tabular}{lllcllll} 
& \multicolumn{1}{c}{$\mathbf{1}$} & \multicolumn{1}{c}{$\mathbf{3}$} & \multicolumn{1}{c}{$\mathbf{5}$} & \multicolumn{1}{c}{$\mathbf{6}$} & \multicolumn{1}{c}{$\mathbf{7}$} & \multicolumn{1}{c}{$\mathbf{8}$} & \multicolumn{1}{c}{$\mathbf{1 0}$} \\
\hline $\mathrm{Ru} 1-\mathrm{C} 4$ & $2.045(3)$ & $2.0586(2)$ & $2.032(4)^{\mathrm{c}}$ & $2.045(2)$ & $2.057(6)$ & $2.099(4)^{\mathrm{c}}$ & $2.046(2)$ \\
$\mathrm{Ru} 1-\mathrm{Cg}{ }^{a}$ & $1.728(3)$ & $1.866(3)$ & $1.905(3)$ & $1.691(2)$ & $1.853(6)$ & $1.856(6)$ & $1.899(4)$ \\
$\mathrm{Ru}-\mathrm{Cl1}$ & $2.4114(7)$ & - & - & $2.4075(6)$ & - & - & - \\
$\mathrm{C} 4-\mathrm{Ru} 1-\mathrm{E}$ & $89.49(1)^{b}$ & $90.45(2)^{b}$ & $89.10(1)^{b, c}$ & $85.94(8)^{d}$ & $86.6(2)^{d}$ & $85.7(3)^{c, d}$ & $91.31(8)^{b}$ \\
\hline \multicolumn{6}{c}{$\mathrm{Cg}=$ centroid of arene/cyclopentadienyl moiety; ${ }^{b} \mathrm{E}={\text { Average position between two alkenyl carbon atoms; }{ }^{c}}^{\mathrm{C} 2 \text { replaces C4 for C(2)-bound (normal) NHC }{ }^{d} \mathrm{E}=\text { Nitrogen atom of pyridyl moiety. }}$}
\end{tabular}

The difficulty in separating complexes $\mathbf{7}$ and $\mathbf{8}$ is demonstrated by the fact that crystallization led repetitively to co-crystallization and afforded crystals that contained both complexes $\mathbf{7}$ and $\mathbf{8}$. Two different unit cells were obtained from X-ray diffraction analysis, each with unique disorders, when either $\mathrm{CH}_{2} \mathrm{Cl}_{2}$ or $\mathrm{CHCl}_{3}$ was used as crystallization solvent (Figures S36, S37). These crystals constitute one of the rare examples where, regardless of the solvent used, disordered crystals contain two co-crystallized complexes as unique polymorphs. Co-crystallization may be facilitated by the similar steric environment that the methylimidazole and pyridyl moieties of the NHC ligand exhibit, ${ }^{24}$ which renders these two entities of the chelating ligand almost identical in each of the complexes.

Selectivity aspects of $\mathbf{C 4 / C 5 - H}$ activation. Different effects may contribute to the low yields obtained for the abnormal carbene complexes, including (i) occurrence of side reactions due to the relatively strong $\mathrm{C} 4-\mathrm{H}$ bond, (ii) the strongly oxidizing nature of $\mathrm{Ag}_{2} \mathrm{O}$ that may cause ligand degradation and/or C2-metallation, (iii) lack of selectivity between C4/C5-unsubstituted ligand precursors, and ensuing divergence of product stability as a result of chelation vs. monodentate bonding. We reasoned that the symmetric carbene precursor $([\mathrm{HL} 4] \mathrm{Cl})$, i.e. the ligand bearing stabilizing alkenyl units adjacent to both the $\mathrm{C}(4)$ and the $\mathrm{C}(5)$ position, alleviates the drawbacks from the low selectivity of Ag carbene formation. Furthermore, L4 features a C(2)-isopropyl substituent that is resistant to Ag-mediated dealkylation, ${ }^{3(b)}$ which further minimizes formation of side products such as normal carbene complexes. Reaction of [HL4]Cl with $\mathrm{Ag}_{2} \mathrm{O}$ and $[(p-$ cymene $\left.) \mathrm{RuCl}_{2}\right]_{2}$ or $\left[\mathrm{CpRuCl}\left(\mathrm{PPh}_{3}\right)_{2}\right]$ gave complexes 9 and 10, respectively (Scheme 4). Yields were indeed significantly higher (62\% and 55\%, for 9 and 10, respectively) and without formation of detectable side-products. 


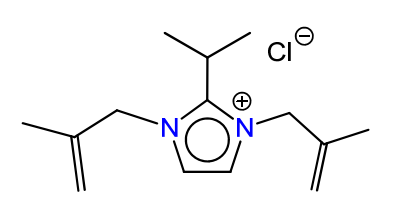

[HL4]Cl

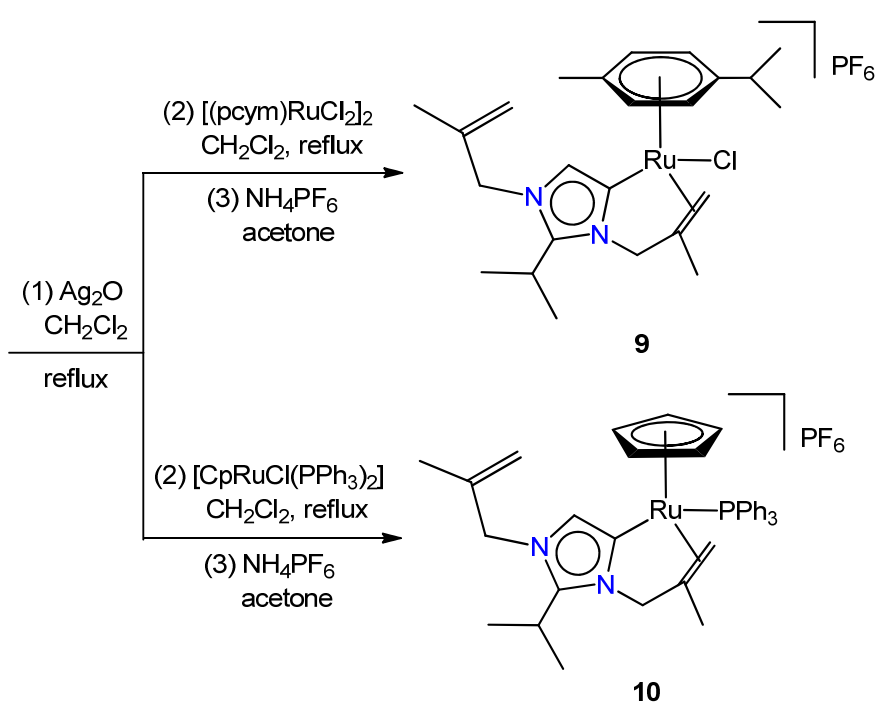

Scheme 4: Formation of the C(2)-isopropyl functionalized Ru(II)-aNHC complexes 9 and $\mathbf{1 0 .}$

Similar to the aNHC ruthenium complexes described above, complexes $\mathbf{9}$ and $\mathbf{1 0}$ showed distinct signals of abnormal carbene bonding in their NMR spectra, including the disappearance of the C(4)$\mathrm{H}$ signal at $\delta_{\mathrm{H}}=7.47$, an upfield shift of the $\mathrm{C}(5)-\mathrm{H}$ resonance to $\delta_{\mathrm{H}}=7.17(\mathbf{9})$ and $6.75(\mathbf{1 0})$, and a downfield shift of the $\mathrm{C}(4)-\mathrm{Ru}$ signal to $\delta \mathrm{C}=152.3(\mathbf{9})$ and 148.6 (10). Chelation was deduced from the shift of the olefinic signals from $\delta_{\mathrm{H}}=4.58$ and 5.06 ([HL4]Cl, $\Delta \delta=0.48 \mathrm{ppm}$ ) to 4.03 and 5.51 $(\mathbf{9}, \Delta \delta=1.48 \mathrm{ppm})$, and to 2.27 and $3.65(\mathbf{1 0}, \Delta \delta=1.38 \mathrm{ppm})$. The molecular structure of $\mathbf{1 0}$ further confirmed the bidentate nature of $\mathbf{L 4}$, with a pseudo-bite angle of $91.31(8)^{\circ}$ and a $\mathrm{Ru}-\mathrm{C}(4)$ bond distance of 2.046(2) $\AA$ (Figure 4), similar to the analogous complexes 1 and 3.

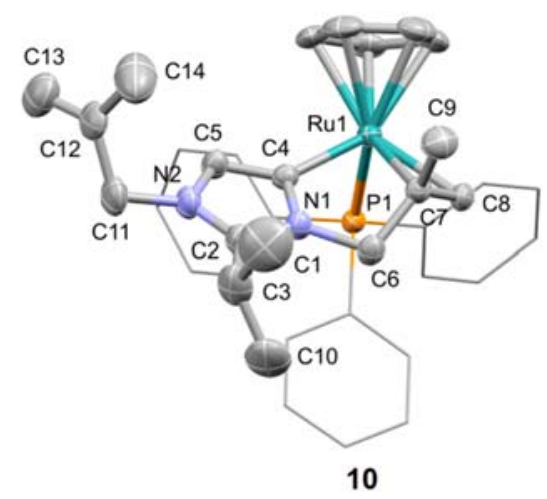

Figure 4: ORTEP plot of compound 10. Thermal ellipsoids are drawn at 50\% level. For clarity, the phenyl moieties of $\mathrm{PPh}_{3}$ are shown as wireframe presentations, and non-coordinating anions and hydrogens are omitted. 
Acid stability. In order to probe the robustness of the $\mathrm{Ru}-\mathrm{C}(4)$ bond in the novel aNHC complexes, the stability of these complexes in an acidic environment was investigated for complexes $\mathbf{1}$ and $\mathbf{3}$ as representatives of p-cymene and cyclopentadienyl systems, respectively. Figure 5 shows the ${ }^{1} \mathrm{H}$ NMR spectra of 1 in acetone- $\mathrm{d}_{6}$ upon addition of various equivalents of $\mathrm{DCl}\left(1 \mathrm{M}, \mathrm{D}_{2} \mathrm{O}\right.$ solution). While up to 12 equivalents of $\mathrm{DCl}$ did not indicate any cleavage of the $\mathrm{Ru}-\mathrm{C} 4$ bond, three distinct events have been identified upon DCl titration of a solution of complex $\mathbf{1}$ :

(i) Rapid H/D isotope exchange at C5: Addition of one equivalent of DCl led to an immediate decrease of the signal at $\delta_{\mathrm{H}} 7.41$ only, and full disappearance after addition of 6 equiv. $\mathrm{DCl}$, indicating deuteration of the $\mathrm{C}(5)$ position. This reactivity was observed in similar aNHC complexes of Ir and Rh, and is indicative of the non-innocent character of the aNHC ligand. ${ }^{15}$ For example, it has been suggested that the strongly mesoionic character of the imidazolylidene ligand may facilitate dearomatization. This is followed by the addition of a proton to a formal metalla-allyl anionic fragment. ${ }^{15(a)}$ The deuteration at $C(5)$ is attributed to the presence of $\mathrm{DCl}$, since a control experiment using only $\mathrm{D}_{2} \mathrm{O}(>12$ equivalents) resulted in no deuteration of the ligand at all. The protio vs. deuterio ratio at $\mathrm{C}(5)$ follows a rapid decrease after addition of $\mathrm{DCl}$ from $80 \%$ (1 eq.) to $29 \%$ (2 eq.), $13 \%$ ( 4 eq.), and $<1 \%$ ( 8 eq.). No formation of the free aNHC ligand or the corresponding imidazolium salt was observed, even upon heating of the solution to $40{ }^{\circ} \mathrm{C}$ for several hours, which underpins the robustness of the Ru-carbene bond.

(ii) p-cymene dissociation: Already in the presence of 1 equivalent of $\mathrm{DCl}$, new signals appeared at $\delta_{\mathrm{H}} 7.09\left(\mathrm{q},{ }^{3} J_{\mathrm{HH}}=6 \mathrm{~Hz}\right), 2.84(\mathrm{~m}), 2.25(\mathrm{~s})$, and $1.20\left(\mathrm{~d},{ }^{3} J_{\mathrm{HH}}=9 \mathrm{~Hz}\right)$, corresponding to free $p$-cymene (17\%; full spectra in Fig. S3, S4). In agreement with cymene loss, the intensity of the doublets corresponding to the coordinated $p$-cymene ligand gradually decreased $\left(c f . \delta_{\mathrm{H}} 6.65,6.50,5.80,5.27\right)$. The relative amount of bound $p$ cymene was $83 \%$ upon addition of 1 eq. $\mathrm{DCl}(2 \mathrm{~h})$, and $70 \%$ in the presence of 8 eq. $\mathrm{DCl}$ (1 day). The signals for the coordinated $p$-cymene ligand do not fully disappear even after addition of 12 equivalents of $\mathrm{DCl}$, which might be indicative of an equilibrium existing between free and bound $p$-cymene. Deuteration of the $\mathrm{C}(5)-\mathrm{H}$ is not expected to affect $p$ cymene dissociation, especially since the signals of coordinated $p$-cymene remain after full deuteration of $\mathrm{C}(5)$.

(iii) Alkene dissociation: Dissociation of the p-cymene ligand generates three available coordination sites on the ruthenium(II) center. With increasing quantities of aqueous DCl, the propensity for the formation of $(\mathrm{aNHC}) \mathrm{Ru}-\mathrm{OD}_{2}$ species increases. ${ }^{25}$ After addition of more than 8 equivalents of $\mathrm{DCl}$, a series of ten new signals appear including three doublets 
at $\delta_{\mathrm{H}} 6.01,5.46$, and 5.31, all with identical coupling constant ${ }^{3} J_{\mathrm{HH}}=6 \mathrm{~Hz}$, in an approximate ratio of 1:4:4. Of the remaining seven singlets $\left(\delta_{\mathrm{H}} 5.07,4.90,4.77,3.98,2.75\right.$, 2.11, and 1.27), the four signals at $\delta_{\mathrm{H}} 5.07,4.90,4.77$, and 1.27 correspond to the free alkenyl tether, suggesting monodentate coordination of the aNHC ligand to the $\mathrm{Ru}(\mathrm{II})$ center. Such bonding indicates that all organic ligands in complex $\mathbf{1}$ are more labile in an acidic environment than the aNHC ligand. After addition of more than 12 equivalents of $\mathrm{DCl}$ and over a period of ten days, the ${ }^{1} \mathrm{H}$ NMR spectrum reveals signals which suggest that a remarkably acid- and moisture-stable aNHC Ru(II) complex remains in solution, although it has lost the $p$-cymene ligand and the $N$-alkenyl tether is unbound. A robust $\mathrm{Ru}-\mathrm{C}_{\mathrm{aNHC}}$ bond is further supported by the carbenic resonance at $\delta_{\mathrm{C}} 171.1$, which remained present over the whole duration of this experiment. Even though the formed compound appears to be stable, attempts to isolate it have not been successful so far.

A similar H/D isotope exchange was observed with the analogous cyclopentadienyl-containing complex 3, where an immediate deuteration of the $\mathrm{C}(5)-\mathrm{H}$ proton was indicated by the loss of the signal at $\delta_{\mathrm{H}}$ 7.02. No sign of deuteration of the cyclopentadienyl or the alkenyl unit was noted. Instead, complex 3 was fairly stable in an acidic environment with the cyclopentadienyl, carbene, and $N$ alkenyl tether remaining intact upon increasing the amounts of added DCl up to 12 equivalents. Addition of $\mathrm{DCl}$ also led to the appearance of new, unassigned signals at $\delta_{\mathrm{H}} 5.27,5.35$, and 5.62. However, no support for the loss of cyclopentadiene was obtained even over prolonged periods of heating to $40{ }^{\circ} \mathrm{C}$ and only a gradual deuteration of all signals was observed after two weeks. 

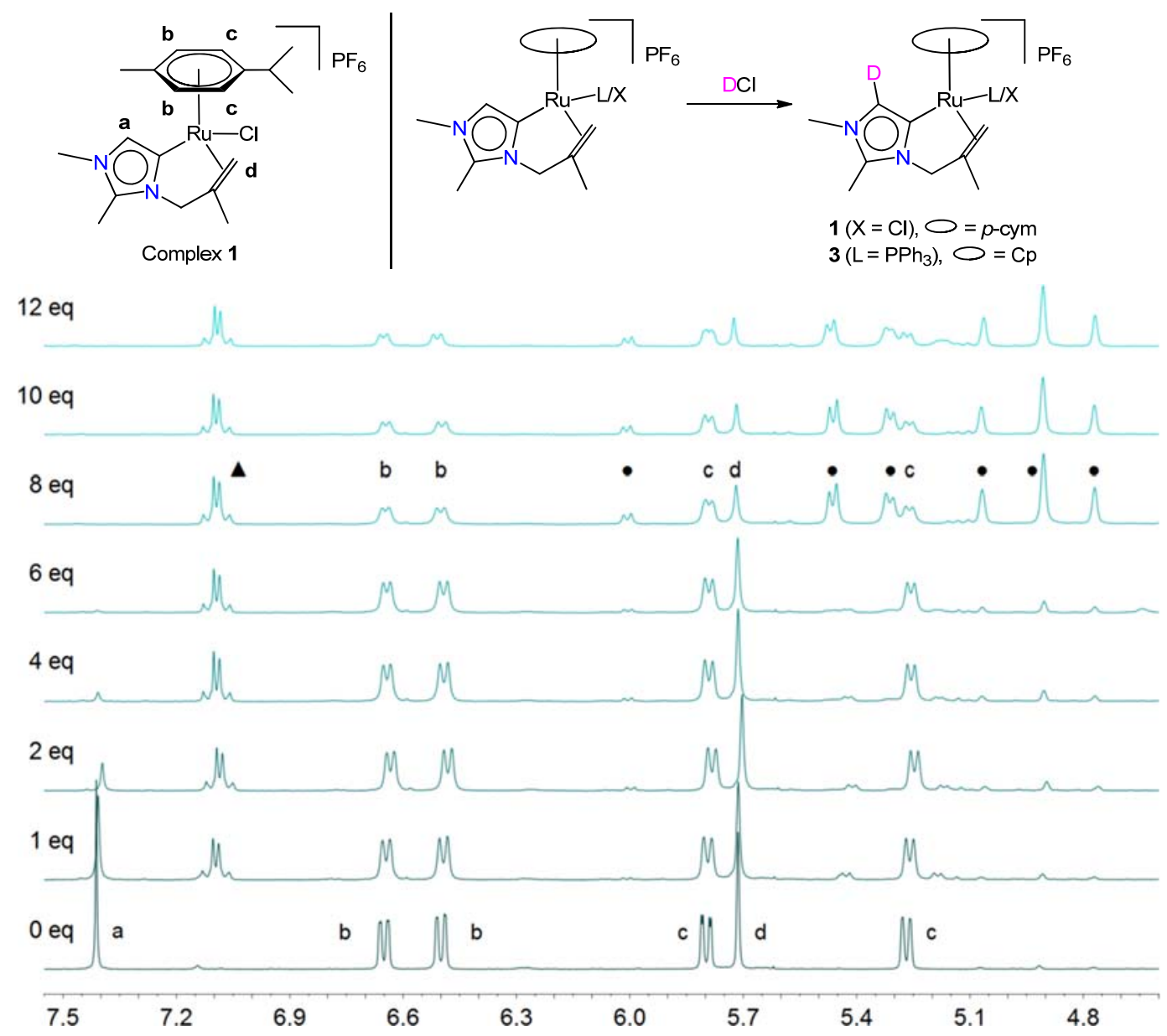

Figure 5: ${ }^{1} \mathrm{H}-\mathrm{NMR}$ spectra of complex 1 upon titration with $\mathrm{DCl}$ showing resonances of complex 1 $(\mathbf{a}-\mathbf{d})$, free $p$-cymene $(\boldsymbol{\Delta})$ and an aNHC Ru complex with non-coordinating $N$-alkenyl tether $(\bullet)$.

Transfer hydrogenation. Similar to the series of normal- and abnormal-NHC Ru(II) complexes described in the literature, ${ }^{26}$ complexes $\mathbf{1}-\mathbf{1 0}$ were active in the transfer hydrogenation of selected ketone compounds. Standard conditions were employed, i.e. excess isopropanol as a hydrogen donor, base $\left(\mathrm{KOH} / \mathrm{KO}{ }^{t} \mathrm{Bu}\right)$ as activator, and benzophenone as model substrate. Both ${ }^{1} \mathrm{H}$ NMR and GC analyses of reaction mixtures in the presence of suitable internal standards suggested a selective reaction, and hence substrate conversions correspond to product yields. After reaction optimization involving catalyst loading, base, and reaction time (see Table S5), complexes 1-10 were screened for their catalytic activity. Using complexes $\mathbf{1}$ ( $p$-cymene) and $\mathbf{3}$ (cyclopentadienyl) as catalysts, initial turnover frequencies TOFini $=60 \mathrm{~h}^{-1}$ and $26 \mathrm{~h}^{-1}$, respectively, were determined $\left(\mathrm{TOF}_{\text {ini }}\right.$ after $15 \mathrm{~min}$ reaction time; Table 2, entries 1,3). While these rates are around three orders of magnitude lower than some of the best-performing ruthenium-based catalysts, ${ }^{2(c), 26}$ they are comparable to similar bidentate 
NHC Ru(II) analogues. ${ }^{2(c), 11(b)}$ Nonetheless, complexes $\mathbf{1}$ and $\mathbf{3}$ performed considerably better than the precursor salts (entries 9,10), revealing a direct impact of the tethered aNHC ligand on the catalytic activity.

Table 2: Transfer hydrogenation of benzophenone using complexes 1-10 ${ }^{a}$

\begin{tabular}{|c|c|c|c|c|c|c|}
\hline & & & {$[\mathrm{Ru}]$} & & & \\
\hline \multirow[t]{2}{*}{ Entry } & \multirow[t]{2}{*}{ Complex } & \multirow{2}{*}{$\begin{array}{c}\text { NHC } \\
N \text {-tether }\end{array}$} & \multirow{2}{*}{$\begin{array}{c}\text { Spectator ligand } \\
\text { system }\end{array}$} & \multicolumn{2}{|c|}{ Conversion $^{c}(\%)$} & \multirow[t]{2}{*}{$\mathrm{TOF}_{\mathrm{ini}}^{d}\left(\mathrm{~h}^{-1}\right)$} \\
\hline & & & & $2 \mathrm{~h}$ & $6 \mathrm{~h}$ & \\
\hline 1 & 1 & alkenyl & $p$-cym/Cl & 63 & 93 & 60 \\
\hline 2 & 2 & alkenyl & $p$-cym/Cl & 52 & 76 & 38 \\
\hline 3 & 3 & alkenyl & $\mathrm{Cp} / \mathrm{PPh}_{3}$ & 32 & 69 & 26 \\
\hline 4 & $4 / 5^{b}$ & alkenyl & $\mathrm{Cp} / \mathrm{PPh}_{3}$ & 37 & 50 & 24 \\
\hline 5 & 6 & picolyl & $p$-cym/Cl & 52 & 73 & 34 \\
\hline 6 & $7 / 8^{b}$ & picolyl & $\mathrm{Cp} / \mathrm{PPh}_{3}$ & 30 & 50 & 22 \\
\hline 7 & 9 & alkenyl & $p$-cym/Cl & 60 & 89 & 58 \\
\hline 8 & 10 & alkenyl & $\mathrm{Cp} / \mathrm{PPh}_{3}$ & 42 & 61 & 46 \\
\hline 9 & {$\left[(p-c y m) \mathrm{RuCl}_{2}\right]_{2}$} & -- & $p$-cym/Cl & n.d. & $8^{e}$ & n.d. \\
\hline 10 & $\left.[\mathrm{Cp}) \mathrm{RuCl}\left(\mathrm{PPh}_{3}\right)_{2}\right]$ & -- & $\mathrm{Cp} / \mathrm{PPh}_{3}$ & n.d. & $6^{\mathrm{e}}$ & n.d. \\
\hline
\end{tabular}

${ }^{a}$ General conditions: Benzophenone (0.6 mmol), iPrOH (5 mL), base (5 mol\%), [Ru] (1 mol\%), reflux. Base used depending on Ru catalyst: $\mathrm{KOH}(\mathbf{1}, \mathbf{2}, \mathbf{6}, \mathbf{9})$; $\mathrm{KO} \mathrm{Bu}(3-5,7, \mathbf{8}, \mathbf{1 0}) ;{ }^{b}$ mixture of complexes as isolated after purification; ${ }^{c}$ determined by GC, based on the average of at least two runs; ${ }^{d}$ determined after the first 15 minutes reaction time; ${ }^{\mathrm{e}}$ after $18 \mathrm{~h}$.

Although chelation generally renders a more robust and longer-lived catalyst, it might inhibit substrate binding and hence reduce the overall yield. ${ }^{2(\mathrm{c}), 26}$ Both complexes $\mathbf{1}$ and $\mathbf{3}$ demonstrate good longevity and provide high yields after $6 \mathrm{~h}$ (93\% for complex 1) and continued activity of complex 3, which reaches a mere $50 \%$ conversion after $6 \mathrm{~h}$ but remains active and accomplishes $81 \%$ conversion after $18 \mathrm{~h}$. When comparing classes of complexes, the $p$-cymene $\mathrm{Ru}(\mathrm{II})$ systems consistently outperformed the cyclopentadienyl $\mathrm{Ru}(\mathrm{II})$ analogues with the same NHC ligand (compare entries 1 vs. 3; 2 vs. 4; 5 vs. 6; 7 vs. 8), presumably because alkoxide coordination is easier by substitution of the chloride ligand than by replacing any of the ligands in the $\mathrm{Cp}$ complexes. For the cyclopentadienyl $\mathrm{Ru}(\mathrm{II})$ complexes to be catalytically active, the most obvious activation pathways include either alkene or phosphine dissociation, which is disfavored due to chelation and 
the strong $\mathrm{Ru}-\mathrm{P}$ bond, respectively ( $c f$. the stability of the alkenyl tether in the $\mathrm{Cp}$ complexes under acidic conditions). The efficiency of the transfer hydrogenation reaction is temperature- and basedependent. Under base-free conditions, only low conversions were obtained that did not exceed 30\% (18 h). Similarly, less than $10 \%$ benzophenone was converted after $6 \mathrm{~h}$ when the reaction was conducted at room temperature. A blank reaction in the absence of a catalyst showed negligible background conversion with $4 \%$ product observed after $18 \mathrm{~h}\left(5 \mathrm{~mol} \% \mathrm{KO}^{\mathrm{t}} \mathrm{Bu}\right)$. A change of the base from $\mathrm{KOH}$ to $\mathrm{KO}^{\text {t}} \mathrm{Bu}$ induced a marginal increase of conversion for the cymene-containing complexes $(6 \%$ after $2 \mathrm{~h})$. The effect is much more substantial with the cyclopentadienyl Ru complexes, which are only very poorly active in the presence of $\mathrm{KOH}$ and required $\mathrm{KO}^{\mathrm{t}} \mathrm{Bu}$ to induce catalytic turnover.

Introduction of a methyl group at $\mathrm{C}(5)$ of the aNHC ligand (complex 2) lowered the performance slightly when compared to the analogue containing a C(5)-H unit (complex 1, cf. entries 1,2), despite the fact that the aNHC ligand in $\mathbf{2}$ is slightly more donating. The lower performance may therefore be attributed to steric effects, which are particularly relevant for inner sphere mechanisms. Changing the chelate from an $\mathrm{N}$-alkene tether to an $\mathrm{N}$-picolyl substituent (complex 6) reduces the catalytic activity of the ruthenium center (entry 1 vs. 5), which highlights the importance of chelate group tailoring. The C(2)-iPr functionalized NHC Ru complex $\mathbf{9}$ performed essentially identical to complex 1, indicating that the $\mathrm{C}(2)$-substituent (Me vs. iPr) on the aNHC ligand does not affect the catalytic activity of the metal center (entry 7). The catalytic activity of the abnormal/normal NHC Ru mixtures $(4 / 5$ and $7 / 8)$ was consistently lower after $6 \mathrm{~h}$, compared to that of the purely aNHC Ru complexes with a $\mathrm{Cp}$ spectator ligand $(\mathbf{3}, \mathbf{1 0}$; $c f$. entries $3,4,6$, and 8$)$, hinting to a beneficial effect of the abnormal NHC bonding mode.

Variation of the substrate demonstrates that steric and electrochemical differences in the substrate notably affect conversion (Table 3), i.e. less bulky substrates (acetophenone vs. benzophenone) and electron-donating substituents such as methoxy-groups resulted in higher conversions (98\%) after 18 h. Conversions were lower with substrates containing electron-withdrawing groups such as 4'-chloroand 4'-nitro-acetophenone (entries 2, 3). In addition, the conversions of 2'- and 4'hydroxyacetophenone substrates were relatively low, presumably because the acidic phenol functionality impedes substrate coordination and instead forms an inactive $\mathrm{Ru}$ phenolate species. 
Table 3: Substrate screening in the transfer hydrogenation reaction using $\mathbf{1}$ as catalyst precursor ${ }^{a}$

\begin{tabular}{|c|c|c|c|c|}
\hline & & {$[\mathrm{Ru}]$} & & \\
\hline \multirow{3}{*}{ Entry } & \multirow{3}{*}{\multicolumn{2}{|c|}{ Substrate }} & \multirow{2}{*}{\multicolumn{2}{|c|}{$\begin{array}{c}\text { Conversion }{ }^{b} \\
(\%)\end{array}$}} \\
\hline & & & & \\
\hline & & & $2 \mathrm{~h}$ & $18 \mathrm{~h}$ \\
\hline 1 & \multicolumn{2}{|c|}{ Benzophenone } & 63 & 96 \\
\hline 2 & \multicolumn{2}{|c|}{ Acetophenone } & 56 & 98 \\
\hline 3 & \multicolumn{2}{|c|}{ 4'-Chloroacetophenone } & 34 & 87 \\
\hline 4 & \multicolumn{2}{|c|}{ 4'-Nitroacetophenone } & 18 & 53 \\
\hline 5 & \multicolumn{2}{|c|}{ 4'-Hydroxyacetophenone } & 24 & 71 \\
\hline 6 & \multicolumn{2}{|c|}{ 2'-Hydroxyacetophenone } & 25 & 76 \\
\hline 7 & \multicolumn{2}{|c|}{ 4'-Methylacetophenone } & 42 & 96 \\
\hline 8 & \multicolumn{2}{|c|}{ 4'-Methoxyacetophenone } & 47 & 98 \\
\hline
\end{tabular}

${ }^{a}$ General conditions: Ketone (0.6 mmol), $i \operatorname{PrOH}(5 \mathrm{~mL}), \mathrm{KOH}(5 \mathrm{~mol} \%),[1]$ (5 mol\%), anisole $(0.3 \mathrm{mmol}), 110^{\circ} \mathrm{C} ;{ }^{b}$ determined by GC, based on the average of at least two runs; calibrations indicate that conversions are identical to yields under these conditions.

Alcohol oxidation. The series of complexes 1-10 was also tested in the anaerobic oxidation of secondary alcohols, where normal NHC analogues of complex 6 featured high activity with TOF $\max$ up to $330 \mathrm{~h}^{-1}$. ${ }^{2(\mathrm{c}), 21}$ The catalytic reactions were performed using $O$-dichlorobenzene as solvent, hexamethylbenzene $(0.1 \mathrm{mmol})$ as internal standard, at a temperature of $150{ }^{\circ} \mathrm{C}$. In general, all complexes catalyze the oxidation at a $5 \mathrm{~mol} \%$ loading and afforded moderate yields of the corresponding ketone (Table 4). Similar to the transfer hydrogenation reaction, the NHC-free complexes $\left(\left[(p-c y m) \mathrm{RuCl}_{2}\right]_{2}\right.$ or $\left[\mathrm{CpRuCl}\left(\mathrm{PPh}_{3}\right)_{2}\right]$ showed very low catalytic activities $(\leq 8 \%$ after 18 hours of reaction time; entries 9,10 in Table 4), indicating a critical role of the tethered aNHC ligand for imparting catalytic activity.

In contrast to transfer hydrogenation catalysis, the alcohol dehydrogenation activity of the ruthenium(II) center is not dependent on the nature of the ancillary ligand set ( $p$-cym/Cl vs. $\mathrm{Cp} / \mathrm{PPh} 3$ ), nor on the type of chelating group ( $\mathrm{N}$-alkenyl vs. $\mathrm{N}$-picolyl). Conversions after $4 \mathrm{~h}$ were generally $60 \pm 5 \%$ ( $72 \pm 5 \%$ after $24 \mathrm{~h}$ ) when using the abnormal NHC Ru(II) complexes (Figure S38), reaching a modest $\mathrm{TOF}_{\max }=9 \mathrm{~h}^{-1}$. Again a notable decrease in catalytic activity is observed with the complexes containing substantial amounts of the normal NHC Ru(II) complex (4/5 and 7/8, entries 4, 6). When 
considering the essentially equal activity of all aNHC $\mathrm{Ru}$ complexes, and the ${ }^{1} \mathrm{H}$ NMR spectroscopically determined ratios of complexes $4 / 5$ (2:1), the catalytic activities of the normal NHC complex in the mixture of $\mathbf{4 / 5}$ is estimated to be about half of that of the abnormal NHC complex. The same accounts for the 1:1 mixture of $\mathbf{7 / 8}$, with the normal NHC imparting only about half the catalytic activity from that of the aNHC ligand.

Table 4: Oxidation of \pm 1 -phenylethanol using 1-10 ${ }^{a}$

\begin{tabular}{|c|c|c|c|}
\hline \multirow{3}{*}{ Entry } & \multicolumn{2}{|c|}{ [Ru] } & O \\
\hline & \multirow{2}{*}{ Complex } & \multicolumn{2}{|c|}{ Conversion ${ }^{c}(\%)$} \\
\hline & & $4 \mathrm{~h}$ & $24 \mathrm{~h}$ \\
\hline 1 & 1 & 63 & 77 \\
\hline 2 & 2 & 60 & 73 \\
\hline 3 & 3 & 58 & 70 \\
\hline 4 & $4 / 5^{b}$ & 50 & 62 \\
\hline 5 & 6 & 62 & 73 \\
\hline 6 & $7 / 8^{b}$ & 43 & 56 \\
\hline 7 & 9 & 57 & 74 \\
\hline 8 & 10 & 58 & 68 \\
\hline 9 & $\left(\left[(p \text {-cym }) \mathrm{RuCl}_{2}\right]_{2}\right.$ & n.d. & $8^{d}$ \\
\hline 10 & {$\left[\mathrm{CpRuCl}\left(\mathrm{PPh}_{3}\right)_{2}\right]$} & n.d. & $8^{d}$ \\
\hline
\end{tabular}

a General conditions: \pm 1 -Phenylethanol (1 mmol), o-dichlorobenzene (5 mL), $\mathrm{KO}^{\mathrm{t}} \mathrm{Bu}(5 \mathrm{~mol} \%),[\mathrm{Ru}](5 \mathrm{~mol} \%)$, hexamethylbenzene $(0.1 \mathrm{mmol}), 150{ }^{\circ} \mathrm{C} ;{ }^{b}$ mixture of complexes as isolated after purification; ${ }^{c}$ determined by $\mathrm{GC}$, based on the average of at least two runs; ${ }^{d}$ after $18 \mathrm{~h}$.

According to the classical transfer hydrogenation and alcohol oxidation mechanisms for $\mathrm{Ru}(\mathrm{II})$ catalysts, a mono-hydride intermediate is proposed. ${ }^{26}$ From the catalysis results of this study it is concluded that generation of available coordination sites for catalysis is mediated in different ways depending on the complex: (i) For all p-cymene complexes, dehalogenation by either $\mathrm{KOH}$ or $\mathrm{KO}^{t} \mathrm{Bu}$ generates an available site for substrate coordination - no NMR resonances for free $p$-cymene could be observed for either transfer hydrogenation, or alcohol oxidation reactions; (ii) For all $\mathrm{Cp}$ complexes, loss of $\mathrm{PPh}_{3}$ as $\mathrm{OPPh}_{3}$ (according to ${ }^{31} \mathrm{P}-\mathrm{NMR}$ spectra) generates an available site for catalysis; (iii) In both transfer hydrogenation and alcohol oxidation reactions, no hydride signals of 
either $p$-cymene or $\mathrm{Cp}$ catalysts could be observed in their ${ }^{1} \mathrm{H}-\mathrm{NMR}$ spectra, and hence it is proposed that the mono-hydride intermediate catalytic species are not the resting state intermediate species.

\section{Conclusions}

Variation of the arene ligand (p-cymene vs. cyclopentadienyl) and of the chelating tether of aNHC ligands (alkenyl vs. picolyl) provided access to six unique half-sandwich aNHC Ru(II) complexes. In addition, Ag-mediated C(2)-demethylation resulted in the identification of two normally-bound NHC $\mathrm{Ru}(\mathrm{II})$ side-products. Symmetrization of the $\mathrm{N}$-alkene substituents of the aNHC ligand, as well as employing an iPr-group on the $\mathrm{C}(2)$-position of the imidazolium precursor, prevented $\mathrm{C}(2)$ dealkylation and allowed for the selective $\mathrm{C}(4)$-ruthenation for both the $p$-cymene and cyclopentadienyl Ru(II) precursors. Preliminary catalytic studies involving transfer hydrogenation suggest a greater impact of vacant coordination sites available via halide substitution ( $p$-cymene $\mathrm{Ru}(\mathrm{II})$ complexes) than via reversible alkene and/or phosphine dissociation (cyclopentadienyl Ru(II) complexes). Furthermore, a slight deactivating effect has been observed for both $p$-cymene and cyclopentadienyl aNHC Ru(II) complexes when employing the less labile $N$-picolyl tether compared to alkenyl chelating groups, and when introducing a methyl group on the aNHC ligand C(5) position. The transfer hydrogenation results indicate that chelating aNHC ligand systems provide a dynamic platform for the development of active, selective, and long-lived catalysts.

\section{Experimental Section}

General. All experiments were carried out under an argon atmosphere using standard Schlenk techniques. Solvents were dried and distilled from appropriate drying agents prior to use. The new imidazolium chloride salts $[\mathrm{H}(\mathbf{L} 1-\mathbf{L} 4)] \mathrm{Cl}$ were synthesized and purified according to standard literature procedures (see SI). ${ }^{27}$ The metal precursor $\left[\mathrm{CpRuCl}\left(\mathrm{PPh}_{3}\right)_{2}\right]$ was synthesized according to the reported method. ${ }^{22}$ All other chemicals were purchased from commercial suppliers and used without further purification. ${ }^{1} \mathrm{H}(300 / 400 \mathrm{MHz})$ and ${ }^{13} \mathrm{C}\{\mathrm{H}\}(76 / 100 \mathrm{MHz})$ NMR spectra were recorded on either a Bruker ARX-300 or a Ultrashield Plus 400 AVANCE 3 spectrometer. All measurements were performed at ambient temperature (298 K), unless otherwise noted. Chemical shifts were referenced to $\mathrm{SiMe}_{4}$ by the internal residual protio solvent resonances. Solid state FT-IR experiments were carried out on a Perkin Elmer Spectrum RXI FT-IR spectrometer as pressed $\mathrm{KBr}$ pellets in air. Microanalytical analyses (\%CHNS) were obtained using a Thermo Scientific Flash 2000 elemental analyzer fitted with a TCD detector. Although some of these results are outside the range viewed as establishing analytical purity (values within $0.4 \%$ ), they are provided to illustrate the 
best values obtained to date. GC analyses were carried out on a Shimadzu GC-2010 fitted with a flame ionization detector (FID) using a TRB-780143 capillary column (30 m, $0.25 \mathrm{~mm}$ ID, thickness $0.25 \mu \mathrm{m})$ and an AOC-20i auto injector. Electrospray mass spectra (ESI-MS) were recorded on a MicromassQuatro LC instrument.

General synthesis of half-sandwich NHC Ru(II) complexes 1-10. A suspension of the appropriate imidazolium chloride salt $[\mathrm{H}(\mathbf{L 1}-\mathbf{L} 4)] \mathrm{Cl}(1 \mathrm{mmol})$ in $\mathrm{CH}_{2} \mathrm{Cl}_{2}(20 \mathrm{~mL})$ containing $\mathrm{Ag}_{2} \mathrm{O}(0.23 \mathrm{~g}, 1$ mmol) was stirred at $30^{\circ} \mathrm{C}$ for $12 \mathrm{~h}$ in the absence of light. The mixture was filtered to which either $\left[(p \text {-cym }) \mathrm{RuCl}_{2}\right]_{2}(0.5 \mathrm{mmol})$ or $\left[\mathrm{CpRuCl}\left(\mathrm{PPh}_{3}\right)_{2}\right](1 \mathrm{mmol})$ was added and heated under reflux for either $5 \mathrm{~h}\left(\left[(p-c y m) \mathrm{RuCl}_{2}\right]_{2}\right)$ or $36 \mathrm{~h}\left(\left[\mathrm{CpRuCl}\left(\mathrm{PPh}_{3}\right)_{2}\right]\right)$. The crude reaction mixture was filtered and the filtrate concentrated in vacuo to $5 \mathrm{~mL}$. Acetone $(15 \mathrm{~mL})$ and $\mathrm{NH}_{4} \mathrm{PF}_{6}(0.16 \mathrm{~g}, 1 \mathrm{mmol})$ were added and the reaction mixture was stirred for a further hour. The mixture was evaporated in vacuo and purified by silica gel column chromatography using gradient elution with $\mathrm{CH}_{2} \mathrm{Cl}_{2}$ /acetone. Yellow to dark-yellow solids were obtained.

Complex 1: Yield: $0.28 \mathrm{~g}, 49 \% .{ }^{1} \mathrm{H}$ NMR $\left(\left(\mathrm{CD}_{3}\right)_{2} \mathrm{CO}\right): \delta_{\mathrm{H}}=1.32\left(\mathrm{~d},{ }^{3} \mathrm{JHH}_{\mathrm{HH}}=6 \mathrm{~Hz}, 3 \mathrm{H}, \mathrm{CH}\left(\mathrm{CH}_{3}\right)_{2}\right)$, $1.34\left(\mathrm{~d},{ }^{3} J_{\mathrm{HH}}=6 \mathrm{~Hz}, 3 \mathrm{H}, \mathrm{CH}\left(\mathrm{CH}_{3}\right)_{2}\right), 1.79\left(\mathrm{~s}, 3 \mathrm{H},=\mathrm{CCH}_{3}\right), 1.98\left(\mathrm{~s}, 3 \mathrm{H}, \mathrm{cym}-\mathrm{CH}_{3}\right), 2.64\left(\mathrm{~s}, 3 \mathrm{H}, \mathrm{C}_{\mathrm{imi}}-\right.$ $\mathrm{CH}_{3}$ ), 2.78 (septet, $\left.{ }^{3} \mathrm{JHH}_{\mathrm{HH}}=6 \mathrm{~Hz}, 1 \mathrm{H}, \mathrm{CHMe}_{2}\right), 3.68\left(\mathrm{~d},{ }^{2} \mathrm{~J}_{\mathrm{HH}}=9 \mathrm{~Hz}, 1 \mathrm{H}, \mathrm{NCH}_{2}\right), 3.85\left(\mathrm{~s}, 3 \mathrm{H}, \mathrm{NCH}_{3}\right)$, $4.07\left(\mathrm{~s}, 1 \mathrm{H},=\mathrm{CH}_{2}\right), 4.44\left(\mathrm{~d},{ }^{2} J_{\mathrm{HH}}=9 \mathrm{~Hz}, 1 \mathrm{H}, \mathrm{NCH}_{2}\right), 5.27\left(\mathrm{~d},{ }^{3} J_{\mathrm{HH}}=6 \mathrm{~Hz}, 1 \mathrm{H}, \mathrm{C}_{\mathrm{cym}} \mathrm{H}\right), 5.71(\mathrm{~s}, 1 \mathrm{H}$, $\left.=\mathrm{CH}_{2}\right), 5.80\left(\mathrm{~d},{ }^{3} J_{\mathrm{HH}}=6 \mathrm{~Hz}, 1 \mathrm{H}, \mathrm{C}_{\mathrm{cymH}}\right), 6.50\left(\mathrm{~d},{ }^{3} J_{\mathrm{HH}}=6 \mathrm{~Hz}, 1 \mathrm{H}, \mathrm{C}_{\mathrm{cymH}}\right), 6.65\left(\mathrm{~d},{ }^{3} J_{\mathrm{HH}}=6 \mathrm{~Hz}, 1 \mathrm{H}\right.$, $\left.\mathrm{C}_{\text {cymH}}\right), 7.41\left(\mathrm{~s}, 1 \mathrm{H}, \mathrm{C}_{\mathrm{imi}} \mathrm{H}\right) .{ }^{13} \mathrm{C}\left\{{ }^{1} \mathrm{H}\right\} \mathrm{NMR}\left(\mathrm{CDCl}_{3}\right): \delta_{\mathrm{C}}=14.1\left(=\mathrm{CCH}_{3}\right), 19.6\left(\mathrm{cym}-\mathrm{CH}_{3}\right), 21.0$ $\left.\left(\mathrm{CH}\left(\mathrm{CH}_{3}\right)_{2}\right), 22.2\left(\mathrm{CH}\left(\mathrm{CH}_{3}\right)_{2}\right), 29.6 \mathrm{C}_{\mathrm{imi}}-\mathrm{CH}_{3}\right), 31.8(\mathrm{cym} \mathrm{CMe}), 54.1\left(\mathrm{NCH}_{3}\right), 60.3\left(\mathrm{NCH}_{2}\right), 80.2$ $\left(=\mathrm{CH}_{2}\right), 81.1$ (=CHMe), $96.6\left(\mathrm{C}_{\text {cymH}}\right), 101.7\left(\mathrm{C}_{\text {cymH}}\right), 115.2\left(\mathrm{C}_{\mathrm{imiH}}\right), 121.5\left(\mathrm{C}_{\text {cym-iPr }}\right), 122.7\left(\mathrm{C}_{\text {cym- }}\right.$ $\mathrm{Me}), 137.6(\mathrm{NCN}), 171.1(\mathrm{C}-\mathrm{Ru}) .{ }^{31} \mathrm{P}\left\{{ }^{1} \mathrm{H}\right\} \mathrm{NMR}\left(\mathrm{CDCl}_{3}\right)$ : $\delta \mathrm{P}=-144.2$ (septet, $\left.{ }^{1} J_{\mathrm{PF}}=713 \mathrm{~Hz}, \mathrm{PF}_{6}\right)$. $\mathrm{CHN}$ found (calcd) for $\left[\mathrm{C}_{19} \mathrm{H}_{28} \mathrm{ClF}_{6} \mathrm{~N}_{2} \mathrm{PRu}\right] \times 1.75 \mathrm{H}_{2} \mathrm{O} \times 0.5 \mathrm{CH}_{2} \mathrm{Cl}_{2}: \mathrm{C}, 36.26$ (36.60), H, 5.25 (5.12), N, 3.98 (4.38)\%. HR-MS (ESI): m/z $421.0962\left(\mathbf{1}^{+}\right)$calcd for $\mathrm{C}_{19} \mathrm{H}_{28} \mathrm{ClN}_{2} \mathrm{Ru} 421.0985$.

Complex 2: Yield: $0.22 \mathrm{~g}, 38 \% .{ }^{1} \mathrm{H}$ NMR $\left(\left(\mathrm{CD}_{3}\right)_{2} \mathrm{CO}\right): \delta_{\mathrm{H}}=1.19\left(\mathrm{~d},{ }^{3} \mathrm{~J}_{\mathrm{HH}}=6 \mathrm{~Hz}, 3 \mathrm{H}, \mathrm{CH}\left(\mathrm{CH}_{3}\right)_{2}\right)$, $1.24\left(\mathrm{~d},{ }^{3} \mathrm{JHH}_{\mathrm{HH}}=6 \mathrm{~Hz}, 3 \mathrm{H}, \mathrm{CH}\left(\mathrm{CH}_{3}\right)_{2}\right), 2.18\left(\mathrm{~s}, 3 \mathrm{H},=\mathrm{CCH}_{3}\right), 2.23\left(\mathrm{~s}, 3 \mathrm{H}, \mathrm{cym}-\mathrm{CH}_{3}\right), 2.29\left(\mathrm{~s}, 3 \mathrm{H}, \mathrm{Cimi}_{-}\right.$ $\left.\mathrm{CH}_{3}\right), 2.35\left(\mathrm{~s}, 3 \mathrm{H}, \mathrm{C}_{\mathrm{imi}}-\mathrm{CH}_{3}\right), 2.79\left(\right.$ septet, $\left.{ }^{3} \mathrm{~J}_{\mathrm{HH}}=6 \mathrm{~Hz}, 1 \mathrm{H}, \mathrm{CHMe}_{2}\right), 3.31\left(\mathrm{~s}, 1 \mathrm{H},=\mathrm{CH}_{2}\right), 3.87(\mathrm{~s}$, $\left.3 \mathrm{H}, \mathrm{NCH}_{3}\right), 4.27\left(\mathrm{~d},{ }^{2} J_{\mathrm{HH}}=15 \mathrm{~Hz}, 1 \mathrm{H}, \mathrm{NCH}_{2}\right), 4.34\left(\mathrm{~d},{ }^{2} J_{\mathrm{HH}}=15 \mathrm{~Hz}, 1 \mathrm{H}, \mathrm{NCH}_{2}\right), 4.75\left(\mathrm{~s}, 1 \mathrm{H},=\mathrm{CH}_{2}\right)$, $5.64\left(\mathrm{~d},{ }^{3} J_{\mathrm{HH}}=6 \mathrm{~Hz}, 1 \mathrm{H}, \mathrm{C}_{\mathrm{cymH}}\right), 5.82\left(\mathrm{~d},{ }^{3} \mathrm{~J}_{\mathrm{HH}}=6 \mathrm{~Hz}, 1 \mathrm{H}, \mathrm{C}_{\text {cymH}}\right), 6.55\left(\mathrm{~d},{ }^{3} J_{\mathrm{HH}}=6 \mathrm{~Hz}, 1 \mathrm{H}, \mathrm{C}\right.$ cymH$)$, $6.64\left(\mathrm{~d},{ }^{3} J_{\mathrm{HH}}=6 \mathrm{~Hz}, 1 \mathrm{H}, \mathrm{C}_{\mathrm{cym}} \mathrm{H}\right) .{ }^{13} \mathrm{C}\left\{{ }^{1} \mathrm{H}\right\} \mathrm{NMR}\left(\mathrm{CDCl}_{3}\right): \delta_{\mathrm{C}}=10.1\left(=\mathrm{CCH}_{3}\right), 18.9\left(\mathrm{cym}-\mathrm{CH}_{3}\right), 22.0$ $\left(\mathrm{CH}\left(\mathrm{CH}_{3}\right)_{2}\right), 23.9\left(\mathrm{CH}\left(\mathrm{CH}_{3}\right)_{2}\right), 27.8\left(\mathrm{Cimi}_{-} \mathrm{CH}_{3}\right), 31.4(\mathrm{cym} \mathrm{CMe}), 34.9\left(\mathrm{C}_{\mathrm{imi}}-\mathrm{CH}_{3}\right), 54.5\left(\mathrm{NCH}_{3}\right)$, 
$70.2\left(\mathrm{NCH}_{2}\right), 78.1\left(=\mathrm{CH}_{2}\right), 78.9\left(=\mathrm{CCH}_{3}\right), 95.0\left(\mathrm{C}_{\text {cymH}}\right), 97.1\left(\mathrm{C}_{\text {cym }}\right), 101.7\left(\mathrm{C}_{\text {cym }}\right), 108.9$ (CimiMe), $117.2\left(\mathrm{C}_{\text {cym-ipr }}\right.$ ), $133.4(\mathrm{NCN}), 168.8(\mathrm{C}-\mathrm{Ru}) .{ }^{31} \mathrm{P}\left\{{ }^{1} \mathrm{H}\right\} \mathrm{NMR}\left(\mathrm{CDCl}_{3}\right)$ : $\delta \mathrm{P}=-144.3$ (septet, ${ }^{1} J_{\mathrm{PF}}=713 \mathrm{~Hz}, \mathrm{PF}_{6}$ ). $\mathrm{CHN}$ found (calcd) for $\left[\mathrm{C}_{20} \mathrm{H}_{30} \mathrm{ClF}_{6} \mathrm{~N}_{2} \mathrm{PRu}\right] \times 0.63 \mathrm{CHCl}_{3}: \mathrm{C}, 38.24$ (37.84), $\mathrm{H}$, 4.30 (4.71), N, 4.31 (4.28)\%. HR-MS (ESI): m/z $435.1152\left(2^{+}\right.$) calcd for $\mathrm{C}_{20} \mathrm{H}_{30} \mathrm{ClN}_{2} \mathrm{Ru} 435.1141$.

Complex 3: Yield: 0.17 g, $23 \%$. ${ }^{1} \mathrm{H}$ NMR ((CD $\left.)_{2} \mathrm{CO}\right): \delta_{\mathrm{H}}=1.70\left(\mathrm{~d},{ }^{2} J_{\mathrm{HH}}=12 \mathrm{~Hz}, 1 \mathrm{H}, \mathrm{NCH}_{2}\right), 1.80$ $\left(\mathrm{s}, 3 \mathrm{H},=\mathrm{CCH}_{3}\right), 2.31\left(\mathrm{~d},{ }^{3} \mathrm{~J}_{\mathrm{HP}}=12 \mathrm{~Hz}, 1 \mathrm{H},=\mathrm{CH}_{2}\right), 2.34\left(\mathrm{~s}, 3 \mathrm{H}, \mathrm{C}_{\mathrm{imi}}-\mathrm{CH}_{3}\right), 3.71\left(\mathrm{~s}, 3 \mathrm{H}, \mathrm{NCH}_{3}\right), 3.80$ $\left(\mathrm{s}, 1 \mathrm{H},=\mathrm{CH}_{2}\right), 3.88\left(\mathrm{~d},{ }^{2} \mathrm{~J}_{\mathrm{HH}}=12 \mathrm{~Hz}, 1 \mathrm{H}, \mathrm{NCH}_{2}\right), 4.97\left(\mathrm{~s}, 5 \mathrm{H}, \mathrm{C}_{5} \mathrm{H}_{5}\right), 7.02(\mathrm{~s}, 1 \mathrm{H}, \mathrm{CimiH}), 7.38-7.49$ $(\mathrm{m}, 15 \mathrm{H}, \mathrm{HPh}) .{ }^{13} \mathrm{C}\left\{{ }^{1} \mathrm{H}\right\} \operatorname{NMR}\left(\mathrm{CDCl}_{3}\right): \delta_{\mathrm{C}}=10.2\left(=\mathrm{CCH}_{3}\right), 31.2\left(\mathrm{C}_{\mathrm{imi}}-\mathrm{CH}_{3}\right), 45.7\left(\mathrm{NCH}_{3}\right), 56.8$ $\left(\mathrm{NCH}_{2}\right), 76.3\left(=\mathrm{CH}_{2}\right), 76.6\left(=\mathrm{CCH}_{3}\right), 87.8\left(\mathrm{C}_{5} \mathrm{H}_{5}\right), 128.0\left(\mathrm{C}_{\mathrm{imiH}}\right), 128.7(\mathrm{CPh}), 130.3\left(\mathrm{CPh}_{\mathrm{Ph}}\right), 133.5$ $(\mathrm{CPh}), 135.2($ ipso-CPh $), 139.2(\mathrm{NCN}), 147.0(\mathrm{C}-\mathrm{Ru}) .{ }^{31} \mathrm{P}\left\{{ }^{1} \mathrm{H}\right\} \mathrm{NMR}\left(\mathrm{CDCl}_{3}\right): \delta \mathrm{P}=-144.2\left(\right.$ septet, ${ }^{1} J_{\mathrm{PF}}$ $\left.=708 \mathrm{~Hz}, \mathrm{PF}_{6}\right), 56.8\left(\mathrm{~s}, \mathrm{PPh}_{3}\right) . \mathrm{CHN}(\%)$ found (calcd) for $\left[\mathrm{C}_{32} \mathrm{H}_{34} \mathrm{~F}_{6} \mathrm{~N}_{2} \mathrm{P}_{2} \mathrm{Ru}\right] \times 2.22\left(\mathrm{CH}_{3}\right)_{2} \mathrm{CO}: \mathrm{C}$, 54.06 (54.46), H, 5.98 (5.59), N, 3.23 (3.29)\%. HR-MS (ESI): m/z $579.1514\left(3^{+}\right.$) calcd for $\mathrm{C}_{32} \mathrm{H}_{34} \mathrm{~N}_{2} \mathrm{PRu} 579.1503$.

Complexes 4 and 5: Complexes 4 and 5 eluted together in a 2:1 ratio. Combined yield: $0.28 \mathrm{~g} \mathrm{(39 \% );}$ By NMR 24\% (4), 15\% (5). Spectroscopic data of 4: ${ }^{1} \mathrm{H}$ NMR $\left(\mathrm{CDCl}_{3}\right): \delta_{\mathrm{H}}=1.45\left(\mathrm{~d},{ }^{2} J_{\mathrm{HH}}=12 \mathrm{~Hz}\right.$, $\left.1 \mathrm{H}, \mathrm{NCH}_{2}\right), 1.85\left(\mathrm{~s}, 3 \mathrm{H},=\mathrm{CCH}_{3}\right), 2.03\left(\mathrm{~d},{ }^{3} \mathrm{~J}_{\mathrm{HP}}=12 \mathrm{~Hz}, 1 \mathrm{H},=\mathrm{CH}_{2}\right), 2.25\left(\mathrm{~s}, 3 \mathrm{H}, \mathrm{C}_{\mathrm{imi}}-\mathrm{CH}_{3}\right), 2.47(\mathrm{~s}$, $\left.3 \mathrm{H}, \mathrm{NCH}_{3}\right), 2.92\left(\mathrm{~s}, 3 \mathrm{H}, \mathrm{C}_{\mathrm{imi}}-\mathrm{CH}_{3}\right), 3.53\left(\mathrm{~d},{ }^{2} J_{\mathrm{HH}}=12 \mathrm{~Hz}, 1 \mathrm{H}, \mathrm{NCH}_{2}\right), 3.78\left(\mathrm{~s}, 1 \mathrm{H},=\mathrm{CH}_{2}\right), 5.02(\mathrm{~s}$, 5H, $\left.\mathrm{C}_{5} \mathrm{H}_{5}\right), 7.31-7.49(\mathrm{~m}, 15 \mathrm{H}, \mathrm{Hph}) .{ }^{13} \mathrm{C}\left\{{ }^{1} \mathrm{H}\right\} \mathrm{NMR}\left(\left(\mathrm{CD}_{3}\right)_{2} \mathrm{CO}\right): \delta_{\mathrm{C}}=9.3\left(=\mathrm{CCH}_{3}\right), 31.8\left(\mathrm{C}_{\mathrm{imi}}-\mathrm{CH}_{3}\right)$, $33.9\left(\mathrm{C}_{\mathrm{imi}}-\mathrm{CH}_{3}\right), 47.6\left(\mathrm{NCH}_{3}\right), 56.6\left(\mathrm{NCH}_{2}\right), 78.4\left(=\mathrm{CH}_{2}\right), 79.8\left(=\mathrm{CCH}_{3}\right), 88.2\left(\mathrm{C}_{5} \mathrm{H}_{5}\right), 117.8$ $\left(\mathrm{C}_{\mathrm{imiM}} \mathrm{Me}\right), 128.7(\mathrm{CPh}), 130.5(\mathrm{CPh}), 131.7(\mathrm{CPh}), 133.5$ (ipso-C $\left.\mathrm{CPh}_{2}\right), 134.3(\mathrm{NCN}), 149.7(\mathrm{C}-\mathrm{Ru})$. ${ }^{31} \mathrm{P}\left\{{ }^{1} \mathrm{H}\right\} \mathrm{NMR}\left(\mathrm{CDCl}_{3}\right): \delta \mathrm{P}=-144.2$ (septet, $\left.{ }^{1} \mathrm{JPF}_{\mathrm{PF}}=708 \mathrm{~Hz}, \mathrm{PF} 6\right), 56.7$ (s, PPh 3$)$. Spectroscopic data of 5: ${ }^{1} \mathrm{H}$ NMR $\left(\mathrm{CDCl}_{3}\right): \delta_{\mathrm{H}}=1.70\left(\mathrm{~s}, 3 \mathrm{H},=\mathrm{CCH}_{3}\right), 2.19\left(\mathrm{~s}, 3 \mathrm{H}, \mathrm{C}_{\mathrm{imi}}-\mathrm{CH}_{3}\right), 2.51\left(\mathrm{~s}, 3 \mathrm{H}, \mathrm{NCH}_{3}\right), 4.36$ $\left(\mathrm{s}, 1 \mathrm{H},=\mathrm{CH}_{2}\right), 4.49\left(\mathrm{~s}, 1 \mathrm{H}, \mathrm{NCH}_{2}\right), 4.64\left(\mathrm{~s}, 1 \mathrm{H},=\mathrm{CH}_{2}\right), 5.02\left(\mathrm{~s}, 5 \mathrm{H}, \mathrm{C}_{5} \mathrm{H}_{5}\right), 5.03\left(\mathrm{~d},{ }^{2} \mathrm{~J}_{\mathrm{HH}}=12 \mathrm{~Hz}, 1 \mathrm{H}\right.$, $\left.\mathrm{NCH}_{2}\right), 6.74\left(\mathrm{~s}, 1 \mathrm{H}, \mathrm{C}_{\mathrm{imiH}} \mathrm{H}\right), 7.52-7.66(\mathrm{~m}, 15 \mathrm{H}, \mathrm{HPh}) .{ }^{13} \mathrm{C}\left\{{ }^{1} \mathrm{H}\right\} \mathrm{NMR}\left(\left(\mathrm{CD}_{3}\right)_{2} \mathrm{CO}\right): \delta_{\mathrm{C}}=9.5\left(=\mathrm{CCH}_{3}\right)$, $31.4\left(\mathrm{C}_{\mathrm{imi}}-\mathrm{CH}_{3}\right), 47.6\left(\mathrm{NCH}_{3}\right), 54.4\left(\mathrm{NCH}_{2}\right), 75.8\left(=\mathrm{CH}_{2}\right), 81.4\left(=\mathrm{CCH}_{3}\right), 87.8\left(\mathrm{C}_{5} \mathrm{H}_{5}\right), 114.6$ $\left(\mathrm{C}_{\mathrm{imiMe}}\right), 121.0\left(\mathrm{C}_{\mathrm{imiH}}\right), 128.6(\mathrm{CPh}), 130.3(\mathrm{CPh}), 131.9(\mathrm{CPh}), 132.7$ (ipso-CPh), $174.0(\mathrm{C}-\mathrm{Ru})$. ${ }^{31} \mathrm{P}\left\{{ }^{1} \mathrm{H}\right\}$ NMR $\left(\mathrm{CDCl}_{3}\right): \delta_{\mathrm{P}}=-144.2$ (septet, $\left.{ }^{1} J_{\mathrm{PF}}=708 \mathrm{~Hz}, \mathrm{PF}_{6}\right), 57.7\left(\mathrm{~s}, \mathrm{PPh}_{3}\right) . \mathrm{CHN}(\%)$ found (calcd) for $\left[\mathrm{C}_{33} \mathrm{H}_{36} \mathrm{~F}_{6} \mathrm{~N}_{2} \mathrm{P}_{2} \mathrm{Ru}\right] \times 0.5\left[\mathrm{C}_{32} \mathrm{H}_{34} \mathrm{~F}_{6} \mathrm{~N}_{2} \mathrm{P}_{2} \mathrm{Ru}\right] \times 0.31 \mathrm{CHCl}_{3}$ : C, 53.22 (52.82), H, 4.26 (4.79), $\mathrm{N}, 4.01$ (3.76)\%. HR-MS (ESI): m/z $593.1619\left(\mathbf{4}^{+}\right), 579.1501\left(5^{+}\right)$calcd for $\mathrm{C}_{33} \mathrm{H}_{36} \mathrm{~N}_{2} \mathrm{PRu}$ (4) 593.1661, $\mathrm{C}_{32} \mathrm{H}_{34} \mathrm{~N}_{2} \mathrm{PRu}(5) 579.1503$. 
Complex 6: Yield: $0.22 \mathrm{~g}, 38 \% .{ }^{1} \mathrm{H}$ NMR $\left(\mathrm{CDCl}_{3}\right): \delta_{\mathrm{H}}=1.20\left(\mathrm{~d},{ }^{3} \mathrm{JHH}_{\mathrm{HH}}=9 \mathrm{~Hz}, 3 \mathrm{H}, \mathrm{CH}\left(\mathrm{CH}_{3}\right)_{2}\right), 1.22$ $\left(\mathrm{d},{ }^{3} \mathrm{~J}_{\mathrm{HH}}=9 \mathrm{~Hz}, 3 \mathrm{H}, \mathrm{CH}\left(\mathrm{CH}_{3}\right)_{2}\right), 1.85\left(\mathrm{~s}, 3 \mathrm{H}, \mathrm{C}_{\mathrm{imi}}-\mathrm{CH}_{3}\right), 2.62\left(\mathrm{~s}, 3 \mathrm{H}, \mathrm{cym}-\mathrm{CH}_{3}\right), 2.75\left(\right.$ septet, ${ }^{3} \mathrm{~J}_{\mathrm{HH}}=$ $\left.9 \mathrm{~Hz}, 1 \mathrm{H}, \mathrm{CHMe}_{2}\right), 3.62\left(\mathrm{~s}, 3 \mathrm{H}, \mathrm{NCH}_{3}\right), 4.88\left(\mathrm{~d},{ }^{2} \mathrm{~J}_{\mathrm{HH}}=15 \mathrm{~Hz}, 1 \mathrm{H}, \mathrm{NCH}_{2}\right), 5.17\left(\mathrm{~d},{ }^{3} \mathrm{JHH}_{\mathrm{HH}}=6 \mathrm{~Hz}, 1 \mathrm{H}\right.$, $\left.\mathrm{C}_{\mathrm{cymH}}\right), 5.35\left(\mathrm{~d},{ }^{2} J_{\mathrm{HH}}=15 \mathrm{~Hz}, 1 \mathrm{H}, \mathrm{NCH}_{2}\right), 5.52\left(\mathrm{~s}, 2 \mathrm{H}, \mathrm{C}_{\mathrm{cymH}}\right), 5.57\left(\mathrm{~d},{ }^{3} \mathrm{JHH}_{\mathrm{HH}}=6 \mathrm{~Hz}, 1 \mathrm{H}, \mathrm{C}_{\text {cymH}}\right)$, $6.58\left(\mathrm{~s}, 1 \mathrm{H}, \mathrm{C}_{\mathrm{imiH}} \mathrm{H}\right), 7.32\left(\mathrm{t},{ }^{3} J_{\mathrm{HH}}=6 \mathrm{~Hz}, 1 \mathrm{H}, \mathrm{C}_{5} \mathrm{H}_{4} \mathrm{~N}\right), 7.61\left(\mathrm{~d},{ }^{3} J_{\mathrm{HH}}=6 \mathrm{~Hz}, 1 \mathrm{H}, \mathrm{C}_{5} \mathrm{H}_{4} \mathrm{~N}\right), 7.77\left(\mathrm{t},{ }^{3} J_{\mathrm{HH}}\right.$ $\left.=6 \mathrm{~Hz}, 1 \mathrm{H}, \mathrm{C}_{5} \mathrm{H}_{4} \mathrm{~N}\right), 9.36\left(\mathrm{~d},{ }^{3} \mathrm{~J}_{\mathrm{HH}}=6 \mathrm{~Hz}, 1 \mathrm{H}, \mathrm{C}_{5} \mathrm{H}_{4} \mathrm{~N}\right) \cdot{ }^{13} \mathrm{C}\left\{{ }^{1} \mathrm{H}\right\} \mathrm{NMR}\left(\mathrm{CDCl}_{3}\right): \delta \mathrm{C}=9.52\left(\mathrm{C}_{\mathrm{imi}}-\right.$ $\left.\mathrm{CH}_{3}\right), 18.1\left(\mathrm{cym}-\mathrm{CH}_{3}\right), 22.3\left(\mathrm{CH}\left(\mathrm{CH}_{3}\right)_{2}\right), 22.5\left(\mathrm{CH}\left(\mathrm{CH}_{3}\right)_{2}\right), 30.6\left(\mathrm{cym} \mathrm{CMe}_{2}\right), 34.4\left(\mathrm{NCH}_{3}\right), 53.0$ $\left(\mathrm{NCH}_{2}\right), 82.0\left(\mathrm{C}_{\text {cymH}}\right), 86.1\left(\mathrm{C}_{\text {cymH}}\right), 88.6\left(\mathrm{C}_{\text {cymH}}\right), 99.5\left(\mathrm{C}_{\text {cymH}}\right), 107.1\left(\mathrm{C}_{\mathrm{py}}\right), 124.6\left(\mathrm{C}_{\mathrm{imiH}}\right), 125.1$ $\left(\mathrm{C}_{\text {cym-iPr }}\right), 125.2\left(\mathrm{C}_{\mathrm{py}}\right), 125.5\left(\mathrm{C}_{\mathrm{cym}}-\mathrm{Me}\right), 139.1(\mathrm{NCN}), 141.9\left(\mathrm{C}_{\mathrm{py}}\right), 150.0\left(\mathrm{C}_{\mathrm{py}}\right), 156.0\left(\mathrm{C}_{\mathrm{py}}\right), 157.8$ $(\mathrm{C}-\mathrm{Ru}) .{ }^{31} \mathrm{P}\left\{{ }^{1} \mathrm{H}\right\} \mathrm{NMR}\left(\mathrm{CDCl}_{3}\right): \delta_{\mathrm{P}}=-144.3$ (septet, $\left.{ }^{1} J_{\mathrm{PF}}=709 \mathrm{~Hz}, \mathrm{PF}_{6}\right) . \mathrm{CHN}(\%)$ found (calcd) for $\left[\mathrm{C}_{21} \mathrm{H}_{27} \mathrm{ClF}_{6} \mathrm{~N}_{3} \mathrm{PRu}\right] \times 0.47 \mathrm{CH}_{2} \mathrm{Cl}_{2}: \mathrm{C}, 40.52$ (40.12), H, 4.52 (4.38), N, 6.17 (6.54)\%. HR-MS (ESI): $\mathrm{m} / \mathrm{z} 458.0948\left(6^{+}\right)$calcd for $\mathrm{C}_{21} \mathrm{H}_{27} \mathrm{ClN}_{3} \mathrm{Ru} 458.0941$.

Complexes 7 and 8: Complexes 7 and $\mathbf{8}$ were obtained as a 1:1 mixture that co-elutes by column chromatography and co-crystallizes upon recrystallization. Combined yield: 0.28 g, 37\%; By NMR: $19 \%$ (7); $18 \%(8)$. Spectroscopic data of 7: ${ }^{1} \mathrm{H} \mathrm{NMR}\left(\mathrm{CDCl}_{3}\right): \delta_{\mathrm{H}}=2.17\left(\mathrm{~s}, 3 \mathrm{H}, \mathrm{C}_{\mathrm{imi}}-\mathrm{CH}_{3}\right), 3.35(\mathrm{~s}$, $\left.3 \mathrm{H}, \mathrm{NCH}_{3}\right), 4.75\left(\mathrm{~s}, 5 \mathrm{H}, \mathrm{C}_{5} \mathrm{H}_{5}\right), 4.80\left(\mathrm{~d},{ }^{2} J_{\mathrm{HH}}=18 \mathrm{~Hz}, 1 \mathrm{H}, \mathrm{NCH}_{2}\right), 5.38\left(\mathrm{~d},{ }^{2} \mathrm{JHH}_{\mathrm{HH}}=18 \mathrm{~Hz}, 1 \mathrm{H}, \mathrm{NCH}_{2}\right)$, $6.64\left(\mathrm{~s}, 1 \mathrm{H}, \mathrm{C}_{\mathrm{imiH}}\right), 6.87-6.92\left(\mathrm{~m}, 5 \mathrm{H}, \mathrm{H}_{\mathrm{Ph}}\right), 7.21-7.36(\mathrm{~m}, 10 \mathrm{H}, \mathrm{Hph}), 7.41-7.54\left(\mathrm{~m}, 3 \mathrm{H}, \mathrm{H}_{\mathrm{py}}\right), 8.25$ $\left(\mathrm{d},{ }^{3} \mathrm{JHH}_{\mathrm{HH}}=6 \mathrm{~Hz}, 1 \mathrm{H}, \mathrm{H}\right.$ py $) .{ }^{13} \mathrm{C}\left\{{ }^{1} \mathrm{H}\right\} \mathrm{NMR}\left(\mathrm{CDCl}_{3}\right): \delta \mathrm{C}=9.6\left(\mathrm{Cimi}_{-} \mathrm{CH}_{3}\right), 37.3\left(\mathrm{NCH}_{3}\right), 55.1\left(\mathrm{NCH}_{2}\right)$, $77.6\left(\mathrm{C}_{5} \mathrm{H}_{5}\right), 122.5\left(\mathrm{C}_{\mathrm{imiH}}\right), 125.4\left(\mathrm{C}_{5} \mathrm{H}_{4} \mathrm{~N}\right), 128.1\left(\mathrm{CPh}_{\mathrm{Ph}}\right), 129.4\left(\mathrm{C}_{\mathrm{Ph}}\right), 129.8\left(\mathrm{CPh}_{\mathrm{Ph}}\right), 133.1\left(\mathrm{C}_{\mathrm{py}}\right), 133.5$ (ipso- $\left.\mathrm{C}_{\mathrm{Ph}}\right), 135.3\left(\mathrm{C}_{\mathrm{py}}\right), 135.9(\mathrm{NCN}), 137.6\left(\mathrm{C}_{\mathrm{py}}\right), 157.3\left(\mathrm{C}_{\mathrm{py}}\right), 159.9(\mathrm{C}-\mathrm{Ru}) .{ }^{31} \mathrm{P}\left\{{ }^{1} \mathrm{H}\right\} \mathrm{NMR}\left(\mathrm{CDCl}_{3}\right)$ : $\delta \mathrm{P}=-144.2$ (septet, $\left.{ }^{1} \mathrm{JPF}_{\mathrm{PF}}=708 \mathrm{~Hz}, \mathrm{PF}_{6}\right), 56.8\left(\mathrm{~s}, P \mathrm{Ph}_{3}\right)$. Spectroscopic data of 8: ${ }^{1} \mathrm{H} \mathrm{NMR}\left(\mathrm{CDCl}_{3}\right)$ : $\delta_{\mathrm{H}}=2.99\left(\mathrm{~s}, 1 \mathrm{H}, \mathrm{NCH}_{3}\right), 4.40\left(\mathrm{~s}, 5 \mathrm{H}, \mathrm{C}_{5} \mathrm{H}_{5}\right), 4.85\left(\mathrm{~d},{ }^{2} J_{\mathrm{HH}}=18 \mathrm{~Hz}, 1 \mathrm{H}, \mathrm{NCH}_{2}\right), 5.34\left(\mathrm{~d},{ }^{2} J_{\mathrm{HH}}=18\right.$ $\left.\mathrm{Hz}, 1 \mathrm{H}, \mathrm{NCH}_{2}\right), 6.34$ (s, 1H, $\left.\mathrm{CimiH}\right), 6.44$ (s, 1H, $\left.\mathrm{CimiH}\right), 6.87-6.92$ (m, 5H, Hph), 7.21-7.36 (m, 10H, $\mathrm{HPh}), 7.41-7.54\left(\mathrm{~m}, 3 \mathrm{H}, \mathrm{H}_{\mathrm{py}}\right), 7.69\left(\mathrm{~d},{ }^{3} \mathrm{~J}_{\mathrm{HH}}=6 \mathrm{~Hz}, 1 \mathrm{H}, \mathrm{H}_{\mathrm{py}}\right) .{ }^{13} \mathrm{C}\left\{{ }^{1} \mathrm{H}\right\} \mathrm{NMR}\left(\mathrm{CDCl}_{3}\right): \delta \mathrm{C}=33.9$ $\left(\mathrm{NCH}_{3}\right), 53.9\left(\mathrm{NCH}_{2}\right), 77.2\left(\mathrm{C}_{5} \mathrm{H}_{5}\right), 123.3\left(\mathrm{C}_{\mathrm{imiH}}\right), 125.3\left(\mathrm{C}_{\mathrm{imi}} \mathrm{H}\right), 128.0\left(\mathrm{C}_{\mathrm{py}}\right), 128.5\left(\mathrm{CPh}_{\mathrm{Ph}}\right), 128.7$ $(\mathrm{CPh}), 130.0\left(\mathrm{CPh}_{\mathrm{Ph}}\right), 133.0\left(\mathrm{C}_{\mathrm{py}}\right), 133.6$ (ipso-CPh), $135.3\left(\mathrm{C}_{\mathrm{py}}\right), 137.0\left(\mathrm{C}_{\mathrm{py}}\right), 156.7\left(\mathrm{C}_{\mathrm{py}}\right), 184.4(\mathrm{C}-\mathrm{Ru})$. ${ }^{31} \mathrm{P}\left\{{ }^{1} \mathrm{H}\right\} \mathrm{NMR}\left(\mathrm{CDCl}_{3}\right): \delta \mathrm{P}=-144.2\left(\right.$ septet, $\left.{ }^{1} J_{\mathrm{PF}}=708 \mathrm{~Hz}, \mathrm{PF} 6\right), 56.0\left(\mathrm{~s}, \mathrm{PPh}_{3}\right) . \mathrm{CHN}(\%)$ found (calcd) for $\left[\mathrm{C}_{34} \mathrm{H}_{33} \mathrm{~F}_{6} \mathrm{~N}_{3} \mathrm{P}_{2} \mathrm{Ru}\right] \times\left[\mathrm{C}_{33} \mathrm{H}_{31} \mathrm{~F}_{6} \mathrm{~N}_{3} \mathrm{P}_{2} \mathrm{Ru}\right] \times 2 \mathrm{CH}_{2} \mathrm{Cl}_{2}$ : C, 49.03 (49.41), H, 4.47 (4.09), N, 5.23 (5.01)\%. HR-MS (ESI): m/z $616.1520\left(7^{+}\right), 602.1279\left(\mathbf{8}^{+}\right)$calcd for $\mathrm{C}_{34} \mathrm{H}_{33} \mathrm{~N}_{3} \mathrm{PRu}$ (7) 616.1460 , $\mathrm{C}_{33} \mathrm{H}_{31} \mathrm{~N}_{3} \mathrm{PRu}(8) 602.1304$. 
Complex 9: Yield: $0.39 \mathrm{~g}, 62 \% .{ }^{1} \mathrm{H}$ NMR $\left(\mathrm{CDCl}_{3}\right): \delta_{\mathrm{H}}=1.23\left(\mathrm{~d},{ }^{3} \mathrm{~J}_{\mathrm{HH}}=6 \mathrm{~Hz}, 3 \mathrm{H}, \mathrm{CH}\left(\mathrm{CH}_{3}\right)_{2}\right), 1.25$ $\left(\mathrm{d},{ }^{3} \mathrm{~J}_{\mathrm{HH}}=6 \mathrm{~Hz}, 3 \mathrm{H}, \mathrm{CH}\left(\mathrm{CH}_{3}\right)_{2}\right), 1.29\left(\mathrm{~d},{ }^{3} \mathrm{~J}_{\mathrm{HH}}=6 \mathrm{~Hz}, 3 \mathrm{H}, \mathrm{CH}\left(\mathrm{CH}_{3}\right)_{2}\right), 1.34\left(\mathrm{~d},{ }^{3} \mathrm{~J}_{\mathrm{HH}}=6 \mathrm{~Hz}, 3 \mathrm{H}\right.$, $\left.\mathrm{CH}\left(\mathrm{CH}_{3}\right)_{2}\right), 1.66\left(\mathrm{~s}, 3 \mathrm{H},=\mathrm{CCH}_{3}\right), 1.74\left(\mathrm{~s}, 3 \mathrm{H},=\mathrm{CCH}_{3}\right), 1.88\left(\mathrm{~s}, 3 \mathrm{H}, \mathrm{cym}-\mathrm{CH}_{3}\right), 2.69$ (septet, ${ }^{3} \mathrm{JHH}_{\mathrm{HH}}=$ $6 \mathrm{~Hz}, 1 \mathrm{H}$, cym-CHMe $), 3.23$ (septet, $\left.{ }^{3} J_{\mathrm{HH}}=6 \mathrm{~Hz}, 1 \mathrm{H}, \mathrm{imi}-\mathrm{CHMe}_{2}\right), 3.73\left(\mathrm{~d},{ }^{2} J_{\mathrm{HH}}=12 \mathrm{~Hz}, 1 \mathrm{H}\right.$, $\left.\mathrm{NCH}_{2}\right), 4.03\left(\mathrm{~s}, 1 \mathrm{H},=\mathrm{CH}_{2}\right), 4.25\left(\mathrm{~d},{ }^{2} J_{\mathrm{HH}}=12 \mathrm{~Hz}, 1 \mathrm{H}, \mathrm{NCH}_{2}\right), 4.57\left(\mathrm{~s}, 2 \mathrm{H},=\mathrm{CH}_{2}\right), 4.61\left(\mathrm{~d},{ }^{2} J_{\mathrm{HH}}=\right.$ $\left.12 \mathrm{~Hz}, 1 \mathrm{H}, \mathrm{NCH}_{2}\right), 4.99\left(\mathrm{~d},{ }^{2} J_{\mathrm{HH}}=12 \mathrm{~Hz}, 1 \mathrm{H}, \mathrm{NCH}_{2}\right), 5.02\left(\mathrm{~d},{ }^{3} J_{\mathrm{HH}}=6 \mathrm{~Hz}, 1 \mathrm{H}, \mathrm{C}_{\mathrm{cym}} \mathrm{H}\right), 5.51(\mathrm{~s}, 1 \mathrm{H}$, $\left.=\mathrm{CH}_{2}\right), 5.63\left(\mathrm{~d},{ }^{3} J_{\mathrm{HH}}=6 \mathrm{~Hz}, 1 \mathrm{H}, \mathrm{C}_{\mathrm{cymH}}\right), 6.28\left(\mathrm{~d},{ }^{3} J_{\mathrm{HH}}=6 \mathrm{~Hz}, 1 \mathrm{H}, \mathrm{C}_{\mathrm{cym} H}\right), 6.42\left(\mathrm{~d},{ }^{3} J_{\mathrm{HH}}=6 \mathrm{~Hz}, 1 \mathrm{H}\right.$, $\left.\mathrm{C}_{\mathrm{cymH}}\right), 7.17(\mathrm{~s}, 1 \mathrm{H}, \mathrm{CimiH}) .{ }^{13} \mathrm{C}\left\{{ }^{1} \mathrm{H}\right\} \mathrm{NMR}\left(\mathrm{CDCl}_{3}\right): \delta \mathrm{C}=15.2\left(=\mathrm{CCH}_{3}\right), 17.3\left(=\mathrm{CCH}_{3}\right), 18.8(\mathrm{cym}-$ $\left.\mathrm{CH}_{3}\right), 19.4\left(\mathrm{CH}\left(\mathrm{CH}_{3}\right)_{2}\right), 19.6\left(\mathrm{CH}\left(\mathrm{CH}_{3}\right)_{2}\right), 24.2\left(\mathrm{CH}\left(\mathrm{CH}_{3}\right)_{2}\right), 24.9\left(\mathrm{CH}\left(\mathrm{CH}_{3}\right)_{2}\right), 26.6\left(\mathrm{CMe}_{2}\right), 30.7$ $\left(\mathrm{CMe}_{2}\right), 53.2\left(\mathrm{NCH}_{2}\right), 56.1\left(\mathrm{NCH}_{2}\right), 90.5\left(=\mathrm{CH}_{2}\right), 93.4\left(=\mathrm{CH}_{2}\right), 95.6\left(=\mathrm{CCH}_{3}\right), 98.2\left(=\mathrm{CCH}_{3}\right), 99.4$ $\left(\mathrm{C}_{\text {cym }}\right), 103.5\left(\mathrm{C}_{\text {cym }}\right), 113.4\left(\mathrm{C}_{\text {cym }}\right), 118.7\left(\mathrm{C}_{\text {cym }}\right), 125.7\left(\mathrm{C}_{\mathrm{imi}} \mathrm{H}\right), 139.5(\mathrm{NCN}), 146.8\left(\mathrm{C}_{\text {cym- }}\right.$ iPr), $148.0\left(\mathrm{C}_{\text {cym }}-\mathrm{Me}\right), 152.3(\mathrm{C}-\mathrm{Ru}) .{ }^{31} \mathrm{P}\left\{{ }^{1} \mathrm{H}\right\} \mathrm{NMR}\left(\mathrm{CDCl}_{3}\right): \delta_{\mathrm{P}}=-144.2$ (septet, ${ }^{1} J_{\mathrm{PF}}=710 \mathrm{~Hz}$ $\mathrm{PF}_{6}$ ). $\mathrm{CHN}(\%)$ found (calcd) for $\left[\mathrm{C}_{24} \mathrm{H}_{36} \mathrm{ClF}_{6} \mathrm{~N}_{2} \mathrm{PRu}\right] \times 0.4 \mathrm{CHCl}_{3}$ : C, 42.73 (42.98), H, 5.29 (5.38), N, 3.89 (4.11)\%. HR-MS (ESI): m/z $489.1612\left(\mathbf{9}^{+}\right)$calcd for $\mathrm{C}_{24} \mathrm{H}_{36} \mathrm{ClN}_{2} \mathrm{Ru} 489.1614$.

Complex 10: Yield: $0.43 \mathrm{~g}, 54 \% .{ }^{1} \mathrm{H}$ NMR $\left(\mathrm{CDCl}_{3}\right): \delta_{\mathrm{H}}=1.01\left(\mathrm{~d},{ }^{3} \mathrm{JHH}_{\mathrm{HH}}=9 \mathrm{~Hz}, 3 \mathrm{H}, \mathrm{CH}\left(\mathrm{CH}_{3}\right) 2\right), 1.24$ $\left(\mathrm{d},{ }^{3} \mathrm{~J}_{\mathrm{HH}}=9 \mathrm{~Hz}, 3 \mathrm{H}, \mathrm{CH}\left(\mathrm{CH}_{3}\right)_{2}\right), 1.55\left(\mathrm{~s}, 3 \mathrm{H},=\mathrm{CCH}_{3}\right), 1.74\left(\mathrm{~s}, 3 \mathrm{H},=\mathrm{CCH}_{3}\right), 1.88\left(\mathrm{~d},{ }^{2} \mathrm{~J}_{\mathrm{HH}}=15 \mathrm{~Hz}\right.$, $\left.1 \mathrm{H}, \mathrm{NCH}_{2}\right), 2.27\left(\mathrm{~d},{ }^{3} J_{\mathrm{HP}}=12 \mathrm{~Hz}, 1 \mathrm{H},=\mathrm{CH}_{2}\right), 3.11\left(\right.$ septet, $\left.{ }^{3} J_{\mathrm{HH}}=9 \mathrm{~Hz}, 1 \mathrm{H}, \mathrm{CHMe}_{2}\right), 3.65(\mathrm{~s}, 1 \mathrm{H}$, $\left.=\mathrm{CH}_{2}\right), 3.84\left(\mathrm{~d},{ }^{2} J_{\mathrm{HH}}=15 \mathrm{~Hz}, 1 \mathrm{H}, \mathrm{NCH}_{2}\right), 4.47\left(\mathrm{~d},{ }^{2} J_{\mathrm{HH}}=15 \mathrm{~Hz}, 1 \mathrm{H}, \mathrm{NCH}_{2}\right), 4.48\left(\mathrm{~s}, 1 \mathrm{H},=\mathrm{CH}_{2}\right)$, $4.58\left(\mathrm{~d},{ }^{2} \mathrm{~J}_{\mathrm{HH}}=15 \mathrm{~Hz}, 1 \mathrm{H}, \mathrm{NCH}_{2}\right), 4.79\left(\mathrm{~s}, 5 \mathrm{H}, \mathrm{C}_{5} \mathrm{H}_{5}\right), 5.28\left(\mathrm{~s}, 1 \mathrm{H},=\mathrm{CH}_{2}\right), 6.75\left(\mathrm{~s}, 1 \mathrm{H}, \mathrm{C}_{\mathrm{imiH}}\right), 7.19-$

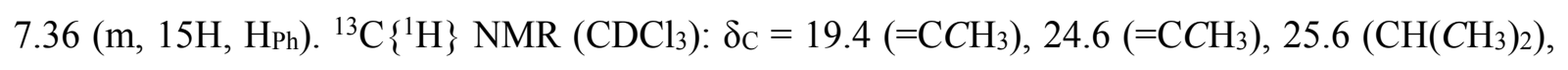
$30.7\left(\mathrm{CMe}_{2}\right), 45.1\left(\mathrm{NCH}_{2}\right), 53.0\left(\mathrm{NCH}_{2}\right), 53.4\left(=\mathrm{CH}_{2}\right), 58.2\left(=\mathrm{CCH}_{3}\right), 68.0\left(=\mathrm{CH}_{2}\right), 77.2\left(=\mathrm{CCH}_{3}\right)$, $88.3\left(\mathrm{C}_{5} \mathrm{H}_{5}\right), 113.0\left(\mathrm{C}_{\mathrm{imiH}}\right), 128.2\left(\mathrm{CPh}_{\mathrm{Ph}}\right), 133.3(\mathrm{CPh}), 135.5\left(\mathrm{CPh}_{\mathrm{Ph}}\right), 140.1$ (ipso- $\left.\mathrm{Cph}_{\mathrm{Ph}}\right), 146.3(\mathrm{NCN})$, $148.6(\mathrm{C}-\mathrm{Ru}) .{ }^{31} \mathrm{P}\left\{{ }^{1} \mathrm{H}\right\} \mathrm{NMR}\left(\mathrm{CDCl}_{3}\right): \delta \mathrm{P}=-144.2$ (septet, $\left.{ }^{1} \mathrm{JPF}_{\mathrm{PF}}=710 \mathrm{~Hz}, \mathrm{PF} 6\right), 57.9(\mathrm{~s}, \mathrm{PPh}) . \mathrm{CHN}$ (\%) found (calcd) for $\left[\mathrm{C}_{37} \mathrm{H}_{42} \mathrm{~F}_{6} \mathrm{~N}_{2} \mathrm{P}_{2} \mathrm{Ru}\right] \times 0.5 \mathrm{H}_{2} \mathrm{O}$ : C, 55.35 (55.50), H, 5.62 (5.41), N, 3.13 (3.50)\%. HR-MS (ESI): m/z $647.2150\left(\mathbf{1 0}^{+}\right)$calcd for $\mathrm{C}_{37} \mathrm{H}_{42} \mathrm{~N}_{2} \mathrm{PRu} 647.2130$.

Typical procedure for transfer hydrogenation catalysis. To a round-bottom flask containing benzophenone (109 mg, $0.6 \mathrm{mmol}$ ), base ( $4 \mathrm{mg}, 0.03 \mathrm{mmol}, 5 \mathrm{~mol} \%$ ), anisole as internal standard (22 $\mu \mathrm{L}, 0.2 \mathrm{mmol})$, and ruthenium complex $(6 \mu \mathrm{mol}, 1 \mathrm{~mol} \%)$ was added 2-propanol $(4 \mathrm{~mL})$ and the reaction mixture was heated to reflux for the time indicated. Aliquots $(0.05 \mathrm{~mL})$ of the reaction mixture taken at specified times were diluted with 2-propanol, and analyzed by GC. Conversions were determined relative to anisole as the internal standard. Aliquots $(0.05 \mathrm{~mL})$ diluted with $\mathrm{CDCl}_{3}$ 
were analyzed by ${ }^{1} \mathrm{H}$ NMR spectroscopy for selected catalytic experiments. More consistent values were determined using GC analysis and conversions were determined relative to anisole as the internal standard. All yields are based on the average of at least two runs.

Typical procedure for alcohol oxidation catalysis. To a round-bottom flask containing \pm 1 phenylethanol (0.121 mg, $1 \mathrm{mmol}), \mathrm{KO}^{\mathrm{t}} \mathrm{Bu}(6 \mathrm{mg}, 0.05 \mathrm{mmol}, 5 \mathrm{~mol} \%)$, hexamethylbenzene as internal standard (18 mg, $0.1 \mathrm{mmol})$, and the ruthenium complex (0.05 mmol, $5 \mathrm{~mol} \%$ ) was added $o$ dichlorobenzene $(4 \mathrm{~mL})$ and the reaction mixture was stirred at $150^{\circ} \mathrm{C}$ for the time indicated. Aliquots $(0.05 \mathrm{~mL})$ of the reaction mixture were diluted with 2-propanol, and conversions were determined by GC analysis relative to hexamethylbenzene as the internal standard. All yields are based on the average of at least two runs.

X-ray crystallography of [HL1]Cl, [HL4]Cl, 1, 3, 4, 5, 6, 7/8.CH $\mathrm{Cl}_{2}, 7 / 8 . \mathrm{CHCl}_{3}$ and 10. Single crystal diffraction studies of the compounds were done using either Quazar multi-layer optics monochromated Mo Ka radiation $(\mathrm{k}=0.71073 \AA)$ on a Bruker D8 Venture kappa geometry diffractometer with duo I $\mu$ s sources, a Photon 100 CMOS detector and APEX II control software ${ }^{28}$ ([HL1]Cl, [HL4] Cl, 3, 6, 7/8. $\mathrm{CH}_{2} \mathrm{Cl}_{2}, \mathbf{7 / 8} . \mathrm{CHCl}_{3}$, and 10), or an Oxford Diffraction SuperNova areadetector diffractometer ${ }^{29}$ using mirror optics monochromated Mo K $\alpha$ radiation $(\lambda=0.71073 \AA)$ and Al filtered ${ }^{30}(\mathbf{1}, \mathbf{5})$. X-ray diffraction measurements were performed at either 123(2) K (1, 5), 150(2) $\mathrm{K}\left([\mathrm{HL1}] \mathrm{Cl}, \mathbf{3}, \mathbf{6}, \mathbf{7} / \mathbf{8} . \mathrm{CH}_{2} \mathrm{Cl}_{2}, \mathbf{7} / \mathbf{8} . \mathrm{CHCl}_{3}\right)$, or 298(2) $\mathrm{K}([\mathrm{HL4}] \mathrm{Cl}, \mathbf{1 0})$. Data reduction was performed using the CrysAlisPro ${ }^{29}$ program. The intensities were corrected for Lorentz and polarization effects, and an absorption correction based on the multi-scan method using SCALE3 ABSPACK in CrysAlisPro ${ }^{29}$ was applied $(\mathbf{1}, \mathbf{5})$. For the remaining compounds: Data reduction was performed using SAINT $+{ }^{28}$ and the intensities were corrected for absorption using SADABS. ${ }^{28}$ The structures were solved by direct methods using SHELXT ${ }^{31}$ using the SHELXL-2014/732 program. The non-hydrogen atoms were refined anisotropically. All $\mathrm{H}$ atoms were placed in geometrically idealized positions and constrained to ride on their parent atoms. For a table containing the data collection and refinement parameters, see Tables S1-S3 in SI. Crystallographic data for all structures have been deposited with the Cambridge Crystallographic Data Centre (CCDC) as supplementary publication numbers) 1843098 ([HL1]Cl), 1843100 ([HL4]Cl), 1843096 (1), 1843103 (3), 1843097 (5), 1843099 (6), 1843101 (7/8.CH $\left.\mathbf{C l}_{2}\right), 1843102$ (7/8.CHCl $)$, and 1843104 (10).

\section{Acknowledgements}

This work has received support from the South African National Research Foundation (ML Grant nr. 93638, FPM Grant nr. 88594), the Central Research Fund of the University of Pretoria (ML) and the 
European Research Council (MA, CoG 615653). Single crystal X-ray diffraction collections and

further assistance by Mr. D. Liles (University of Pretoria), Dr. Jürg Hauser and Dr. Piero Macchi (Universität Bern) are gratefully acknowledged.

\section{Associated Content}

The SI document contains the crystallographic details for all structures, crystallographic data files (in CIF format), CCDC identifier codes (1843096-1843104), ${ }^{1} \mathrm{H},{ }^{13} \mathrm{C}$, and ${ }^{31} \mathrm{P}$ NMR spectra, as well as time-resolved catalytic profiles (PDF format).

\section{Author Information}

Corresponding Authors

*E-mail for M.A.: martin.albrecht@dcb.unibe.ch.

*E-mail for M.L.: marile.landman@up.ac.za.

\section{Notes}

The authors declare no competing financial interest.

\section{References}


(1) (a) Nolan, S. P. (ed.) N-Heterocyclic Carbenes: Effective Tools for Organometallic Synthesis. Wiley VCH: Germany, 2014, ISBN: 978-3-527-33490-2. (b) Diez-Gonzalez, S. (ed.) N-Heterocyclic Carbenes: From Laboratory to Curiosities to Efficient Synthetic Tools. Royal Society of Chemistry: United Kingdom, 2nd ed., 2016, ISBN: 978-1782624233. (c) Hopkinson, M. N.; Richter, C.; Schedler, M.; Glorius, F. An overview of N-heterocyclic carbenes. Nature 2014, 510, 485-496. (d) Schuster, O.; Yang, L.; Raubenheimer, H. G.; Albrecht, M. Beyond Conventional N-Heterocyclic Carbenes: Abnormal, Remote, and Other Classes of NHC Ligands with Reduced Heteroatom Stabilization. Chem. Rev. 2009, 109, 3445-3478.

(2) (a) Munz, D. Pushing Electrons - Which Carbene Ligand for Which Application? Organometallics 2018, 37, 275-289. (b) Peris, E. Smart N-Heterocyclic Carbene Ligands in Catalysis. Chem. Rev. 2017, 118, 9988-10031. (c) Vivancos, Á.; Segarra, C.; Albrecht, M. Mesoionic and Related Less Heteroatom-Stabilized N Heterocyclic Carbene Complexes: Synthesis, Catalysis, and Other Applications. Chem. Rev. 2018, 118, 9493-9586.

(3) (a) Waters, J. B.; Goicoechea, J. M. Coordination chemistry of ditopic carbanionic N-heterocyclic carbenes. Coord. Chem. Rev. 2015, 293-294, 80-94. (b) Albrecht, M. C4-bound imidazolylidenes: from curiosities to high-impact carbene ligands. Chem. Commun. 2008, 31, 3601-3610. (c) Ghadwal, R. S. Carbon-based two electron $\sigma$-donor ligands beyond classical N-heterocyclic carbenes. Dalton Trans. 2016, 45, 16081-16095.

(4) (a) Arnold, P. L.; Pearson, S. Abnormal N-heterocyclic carbenes. Coord. Chem. Rev. 2007, 251, 596609. (b) Crabtree, R. H. Abnormal, mesoionic and remote N-heterocyclic carbene complexes. Coord. Chem. Rev. 2013, 257, 755-766.

(5) (a) Aldeco-Perez, E.; Rosenthal, A. J.; Donnadieu, B.; Parameswaran, P.; Frenking, G.; Bertrand, G. Isolation of a C5-Deprotonated Imidazolium, a Crystalline "Abnormal" N-Heterocyclic Carbene. Science, 2009, 326, 556-559. (b) Bernhammer, J. C.; Frison, G.; Huynh, H. V. Electronic Structure Trends in N Heterocyclic Carbenes (NHCs) with Varying Number of Nitrogen Atoms and NHCTransition Metal Bond Properties. Chem. Eur. J. 2013, 19, 12892-12905.

(6) (a) Rottschäfer, D.; Ebeler, F.; Strothmann, T.; Neumann, B.; Stammler, H.-G.; Mix, A.; Ghadwal, R. S. The Viability of C5-Protonated- and C4,C5-Ditopic Carbanionic Abnormal NHCs: A New Dimension in NHC Chemistry. Chem. Eur. J. 2018, 24, 3716-3720. (b) Karthik, V.; Gupta, V.; Anantharaman, G. Synthesis of Imidazole-Based Functionalized Mesoionic Carbene Complexes of Palladium: Comparison of Donor Properties and Catalytic Activity toward Suzuki-Miyaura Coupling. Organometallics 2014, 33, 6218-6222.

(7) (a) Saha, S.; Daw, P.; Bera, J. K. Oxidative Route to Abnormal NHC Compounds from Singly Bonded $[\mathrm{M}-\mathrm{M}](\mathrm{M}=\mathrm{Ru}, \mathrm{Rh}, \mathrm{Pd})$ Precursors. Organometallics 2015, 34, 5509-5512. (b) Rottschäfer, D.; 
Schürmann, C. J.; Lamm, J-H.; Paesch, A. N.; Neumann, B.; Ghadwal, R. S. Abnormal-NHC Palladium(II) Complexes: Rational Synthesis, Structural Elucidation, and Catalytic Activity. Organometallics 2016, 35, 3421-3429.

(8) (a) Krüger, A.; Kluser, E.; Müller-Bunz, H.; Neels, A.; Albrecht, M. Chelating C4-Bound Imidazolylidene Complexes through Oxidative Addition of Imidazolium Salts to Palladium(0). Eur. J. Inorg. Chem. 2012, 1394-1402. (b) Segarra, C.; Mas-Marzá, J. A.; Mata, Peris, E. Rhodium and Iridium Complexes with Chelating $\mathrm{C}-\mathrm{C}^{\prime}$-Imidazolylidene-Pyridylidene Ligands: Systematic Approach to Normal, Abnormal, and Remote Coordination Modes. Organometallics 2012, 31, 51695176.

(9) (a) Schaper, L-A.; Öfele, K.; Kadyrov, R.; Bechlars, B.; Drees, M.; Cokoja, M.; Herrmann, W. A.; Kühn, F. E. N-Heterocyclic carbenes via abstraction of ammonia: 'normal' carbenes with 'abnormal' character. Chem. Commun. 2012, 48, 3857-3859. (b) Y. Kim, E. Lee, Activation of C-F bonds in fluoroarenes by N-heterocyclic carbenes as an effective route to synthesize abnormal NHC complexes. Chem. Commun. 2016, 52, 10922-10925.

(10) Martin, D.; Melaimi, M.; Soleilhavoup, M.; Bertrand, G. A Brief Survey of Our Contribution to Stable Carbene Chemistry. Organometallics 2011, 30, 5304-5313.

(11) (a) Saha, S.; Ghatak, T.; Saha, B.; Doucet, H.; Bera, J. K. Steric Control at the Wingtip of a Bis-NHeterocyclic Carbene Ligand: Coordination Behavior and Catalytic Responses of Its Ruthenium Compounds. Organometallics 2012, 31, 5500-5505. (b) Hollering, M.; Weiss, D. T.; Bitzer, M. J.; Jandl, C.; Kühn, F. E. Controlling Coordination Geometries: Ru-Carbene Complexes with Tetra-NHC Ligands. Inorg. Chem. 2016, 55, 6010-6017.

(12) Juzgado, A.; Lorenzo-García, M. M.; Barrejón, M.; Rodríguez, A. M.; Rodríguez-López, J.; Merino, S.; Tejeda, J. Chelation assistance as a tool for the selective preparation of an imidazole-based mesoionic palladium carbene complex. Chem. Commun. 2014, 50, 15313-15315.

(13) (a) Witt, J.; Pöthig, A.; Kühn, F. E.; Baratta, W. Abnormal N Heterocyclic Carbene-Phosphine Ruthenium(II) Complexes as Active Catalysts for Transfer Hydrogenation. Organometallics 2013, 32, 4042-4045. (b) Krüger, A.; Albrecht, M. Abnormal N-heterocyclic Carbenes: More than Just Exceptionally Strong Donor Ligands. Aust. J. Chem. 2011, 64, 1113-1117.

(14) (a) Filonenko, G. A.; Cosimi, E.; Lefort, L.; Conley, M. P.; Copéret, C.; Lutz, M.; Hensen, E. J. M.; Pidko, E. A. Lutidine-Derived Ru-CNC Hydrogenation Pincer Catalysts with Versatile Coordination Properties. ACS Catalysis 2014, 4, 2667-2671. (b) Ellul, C. E.; Mahon, M. F.; Saker, O.; Whittlesey, M. K. Abnormally Bound N Heterocyclic Carbene Complexes of Ruthenium: C-H Activation of Both C4 and C5 Positions in the Same Ligand. Angew. Chem. Int. Ed. 2007, 46, 6343-6345. 
(15) (a) Petronilho, A.; Woods, J. A.; Mueller-Bunz, H.; Bernhard, S.; Albrecht, M. Iridium Complexes Containing Mesoionic C Donors: Selective C(sp3)-H versus C(sp2)-H Bond Activation, Reactivity Towards Acids and Bases, and Catalytic Oxidation of Silanes and Water. Chem. Eur. J. 2014, 20, 15775-15784. (b) Krüger, A.; Albrecht, M. Rhodium Carbene Complexes as Versatile Catalyst Precursors for Si-H Bond Activation. Chem. Eur. J. 2012, 18, 652-658.

(16) See the SI for X-ray analysis of ligands [HL1]Cl and [HL4]Cl.

(17) Liske, A.; Verlinden, K.; Buhl, H.; Schaper, K.; Ganter, C. Determining the $\pi$-Acceptor Properties of N-Heterocyclic Carbenes by Measuring the 77Se NMR Chemical Shifts of Their Selenium Adducts. Organometallics 2013, 32, 5269-5272.

(18) Gandolfi, C.; Heckenroth, M.; Neels, A.; Laurenczy, G.; Albrecht, M. Chelating NHC Ruthenium(II) complexes as Robust Homogeneous Hydrogenation Catalysts. Organometallics 2009, 28, 51125121.

(19) Other metalation procedures afforded complex 1 in much lower yield. For example, reaction of $\mathrm{HL1}] \mathrm{Cl}$ with a base followed by metalation with [(cym) $\left.\mathrm{RuCl}_{2}\right]_{2}$ gave $\mathbf{1}$ in only $22 \%$ and $11 \%$ if the base was $\mathrm{KO}^{t} \mathrm{Bu}$ and $\mathrm{NaH}$, respectively. Isolation of the silver carbene intermediate lowered yields also substantially as the silver carbene complex rapidly decomposed to the protonated ligand. Despite the moderate absolute yield, the in situ transmetalation protocol therefore affords the highest yield of all procedures evaluated.

(20) While separation of complexes 4 and 5 was not achieved, a few single crystals of pure 5 were isolated from fractional crystallization for an X-ray diffraction analysis, although not in sufficient quantities for further analysis.

(21) Bolje, A.; Hohloch, S.; Urankar, D.; Pevec, A.; Gazvoda, M.; Sarkar, B.; Košmrlj, J. Exploring the Scope of Pyridyl- and Picolyl-Functionalized 1,2,3-Triazol-5-ylidenes in Bidentate Coordination to Ruthenium(II) Cymene Chloride Complexes. Organometallics 2014, 33, 2588-2598.

(22) Gorbachuk, E. V.; Badeeva, E. K.; Zinnatullin, R. G.; Pavlov, P. O.; Dobrynin, A. B.; Gubaidullin, A. T.; Ziganshin, M. A.; Gerasimov, A. V.; Sinyashin, O. G.; Yakhvarov, D. G. Polymorphism and thermodynamic properties of chloro(cyclopentadienyl)-bis(triphenylphosphine)ruthenium(II) complex. J. Organomet. Chem. 2016, 805, 49-53.

(23) Daw, P.; Petakamsetty, R.; Sarbajna, A.; Laha, S.; Ramapanicker, R.; Bera, J. K. A Highly Efficient Catalyst for Selective Oxidative Scission of Olefins to Aldehydes: Abnormal-NHC-Ru(II) Complex in Oxidation Chemistry. J. Am. Chem. Soc., 2014, 136, 13987-13990. 
(24) Leigh, V.; Ghattas, W.; Lalrempuia, R.; Müller-Bunz, H.; Pryce, M. T.; Albrecht, M. Synthesis, Photo-, and Electrochemistry of Ruthenium Bis(bipyridine) Complexes Comprising a N-heterocyclic Carbene Ligand. Inorg. Chem. 2013, 52, 5395-5402.

(25) Bíró, L.; Farkas, E.; Buglyó P. Hydrolytic behaviour and chloride ion binding capability of $\left[\mathrm{Ru}\left(\eta^{6}-p-\right.\right.$ cym $\left.)\left(\mathrm{H}_{2} \mathrm{O}\right)_{3}\right]^{2+}$ : a solution equilibrium study. Dalton Trans. 2012, 41, 285-291.

(26) Hey, D. A.; Reich, R. M.; Baratta, W.; Kühn, F. E. Current advances on ruthenium(II) Nheterocyclic carbenes in hydrogenation reactions. Coord. Chem. Rev. 2018, 374, 114-132.

(27) (a) Malan, F. P.; Singleton, E.; van Rooyen, P. H.; Landman, M. Facile Suzuki-Miyaura coupling of activated aryl halides using new $\mathrm{CpNiBr}(\mathrm{NHC})$ complexes. J. Organomet. Chem. 2016, 813, 7-14. (b) Fraser, R.; van Rooyen, P. H.; de Lange, J.; Cukrowski, I.; Landman, M. Synthesis, structure and DFT study of asymmetrical NHC complexes of cymantrene derivatives and their application in the dehydrogenative dimerization reaction of thiols. J. Organomet. Chem. 2017, 840, 11-22.

(28) APEX2 (including SAINT and SADABS), Bruker AXS Inc., Madison, WI, 2012.

(29) Oxford Diffraction (2010). CrysAlisPro (Version 1.171.34.44). Oxford Diffraction Ltd., Yarnton, Oxfordshire, UK.

(30) Macchi, P.; Bürgi, H.-B.; Chimpri, A. S.; Hauser, J.; Gál, Z. Low-energy contamination of Mo microsource X-ray radiation: analysis and solution of the problem. J. Appl. Cryst. 2011, 44, 763-771.

(31) Sheldrick, G. M. SHELXT - Integrated space-group and crystal-structure determination. Acta Cryst. 2015, A71, 3-8.

(32) Sheldrick, G. M. Crystal structure refinement with SHELXL. Acta Cryst. 2015, C71, 3-8.

For table of contents use only

\section{Graphical abstract}




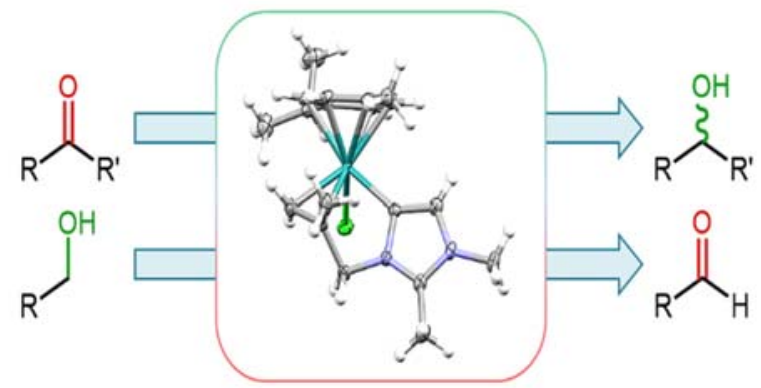

